San Jose State University

SJSU ScholarWorks

Master's Theses

Master's Theses and Graduate Research

1991

\title{
The new man and the new world the influence of Renaissance humanism on the explorers of the Italian era of discovery
}

Richard Di Giacomo

San Jose State University

Follow this and additional works at: https://scholarworks.sjsu.edu/etd_theses

\section{Recommended Citation}

Di Giacomo, Richard, "The new man and the new world the influence of Renaissance humanism on the explorers of the Italian era of discovery" (1991). Master's Theses. 107.

DOI: https://doi.org/10.31979/etd.583f-m57m

https://scholarworks.sjsu.edu/etd_theses/107

This Thesis is brought to you for free and open access by the Master's Theses and Graduate Research at SJSU ScholarWorks. It has been accepted for inclusion in Master's Theses by an authorized administrator of SJSU ScholarWorks. For more information, please contact scholarworks@sjsu.edu. 


\section{INFORMATION TO USERS}

This manuscript has been reproduced from the microfilm master. UMI films the text directly from the original or copy submitted. Thus, some thesis and dissertation copies are in typewriter face, while others may be from any type of computer printer.

The quality of this reproduction is dependent upon the quality of the copy submitted. Broken or indistinct print, colored or poor quality illustrations and photographs, print bleedthrough, substandard margins, and improper aligniment can adversely affect reproduction.

In the unlikely event that the author did not send UMI a complete manuscript and there are missing pages, these will be noted. Also, if unauthorized copyright material had to be removed, a note will indicate the deletion.

Oversize materials (e.g., maps, drawings, charts) are reproduced by sectioning the original, beginning at the upper left-hand corner and continuing from left to right in equal sections with small overlaps. Each original is also photographed in one exposure and is included in reduced form at the back of the book.

Photographs included in the original manuscript have been reproduced xerographicaliy in this copy. Higher quality 6" $\times 9$ " black and white photographic prints are available for any photographs or illustrations appearing in this copy for an additional charge. Contact UMI directly to order.

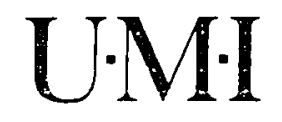

University Microfilms Internatıonal

A Bell \& Howell Information Company 300 North Zeeb Road. Ann Arbor. Ml 48106-1346 USA

$313 / 761-4700 \quad 800,521-0600$ 


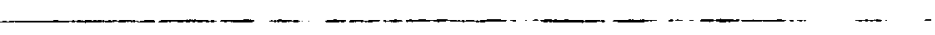


Order Number 1344253

The new man and the new world: The influence of Renaissance humanism on the explorers of the Italian Era of Discovery

Di Giacomo, Richard, M.A.

San Jose State University, 1991

Copyright (C1991 by Di Giacomo, Richard. Áll rights reserved.

$\mathrm{U} \cdot \mathrm{M} \cdot \mathrm{I}$

300 N. Zeeb Rd.

Ann Arbor, MI 48106 

THE NEW MAN AND THE NEW WORLD:

THE INFLUENCE OF RENAISSANCE HUMANISM ON THE EXPLORERS OF THE ITALIAN ERA OF DISCOVERY

\author{
A Thesis \\ Presented to \\ The Faculty of the Deperiment of History \\ Sen Josỉ State Untuersity \\ In Portial Fulfiliment \\ of the Requirements for the Degree \\ Mester of Arts
}

By

Richard DI Giacomo

May, 1991 
APPROVED FOR THE DEPARTMENT OF HISTORY

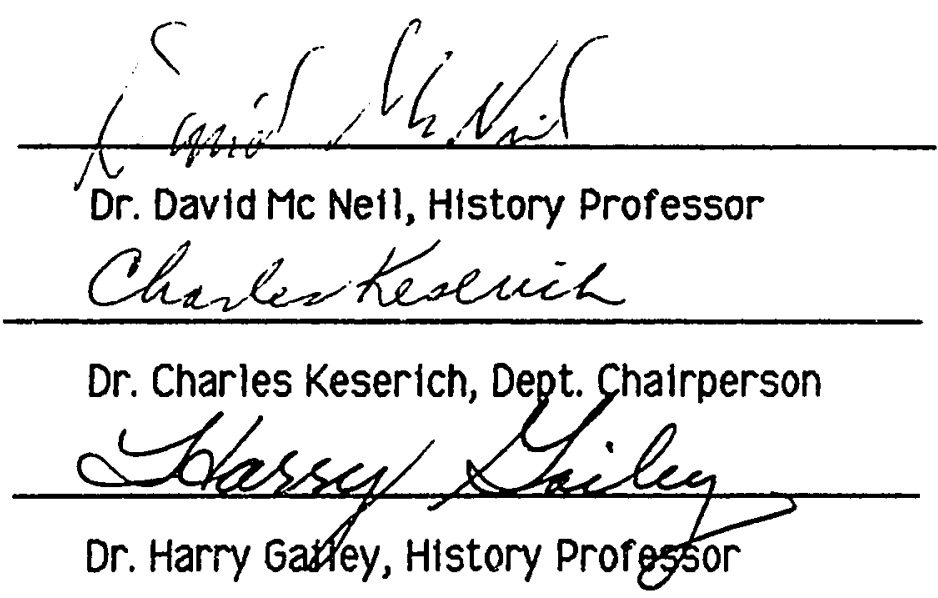

APPROVED FOR THE UNIVERSITY

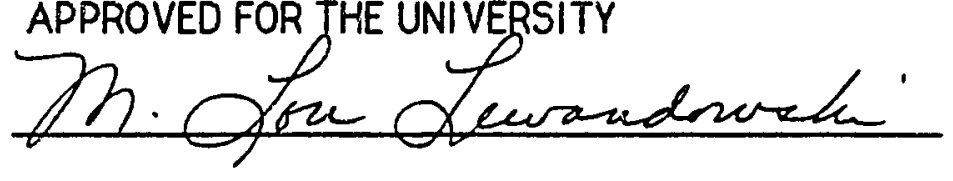


01991

Richerd DI Glecomo

ALL RIGHTS RESERVED 


\begin{abstract}
THE NEW MAN AND THE NEW WORLD:

THE INFLUENCE OF RENAISSANCE HUMANISM ON

THE EXPLORERS OF THE ITALIAN ERA OF DISCOYERY

The collective discoveries of Christopher Columbus, Amerigo

Vespuccl, John and Sebestian Cabot, and Glovanni da Verrazzeno constitute a

distinct Itelian Ero of Discovery which laid the groundwork for all other

voyeges which followed. The Itolien discoverers deserve o place olongside

the well-known Humanists in the history of ort, literature, philosophy, and

government by virtue of their research end accomplishments. The explorers

also made original contributions to the fields of science, nevigation and
\end{abstract} cartogrophy.

The world view of the Italien explorers evolved to include the concept of a new world. They hed to reevaluate their cosmography and chenge the maps to reflect their new knowledge. The concept of a New World was equally profound as that of a new age. The most importent contribution of the Itelion explorers was not what they found, but the chenge in thinking that took plece when they tried to explein their discoveries. 
Toble of Contents

Chepter

1. Introduction $\ldots \ldots \ldots \ldots \ldots \ldots \ldots \ldots \ldots \ldots$. i

The Italion Ero of Discovery $\ldots \ldots \ldots \ldots \ldots \ldots$. 5

2. Christopher Columbus $\ldots \ldots \ldots \ldots \ldots \ldots \ldots 24$

3. Amerigo Vespucci $\ldots \ldots \ldots \ldots \ldots \ldots \ldots . \ldots . \ldots$

4. John and Sebastion Cabot $\ldots \ldots \ldots \ldots \ldots \ldots$........ 80

6. Gloyanni do Verrazzeno .................. 108

7. The Impect of the Age of Discovery on Italy ..... 124 Conclusion ........................ 127

\section{Appendixes}

A. Itelien Voyeges of Discovery $\ldots \ldots \ldots \ldots \ldots \ldots 132$

B. Chronology of the Itelien Ero of Discovery ..... 133 


\section{CHAPTER I}

\section{IRTRODUCTION}

Scholers have long debeted the differences between the Middle Ages and the Reneissance, ant an important part of this debote has been the discussion over what distinguishes the Renaissance man from his predecessors. Ever since the eppearance of the seminel chapters in Jecob Burckhardt's The Ciyilization of the Renaissence in Itoly.' which discussed the matter, countless followers and detractors of Burckhardt heve yentured their own lists of which quelities do or do not typify the Renaissence men.

Over the years o kind of litmus test for the Renaissence men has evolved with yaried, but nonetheless generally common characteristics. The Reneissance man had: the first true aworeness of man's location in time and spece because of his study of geogrophy, history, and netural philosophy; ${ }^{2}$ o more occurate sense of history; ${ }^{3}$ and o distinct awereness of being pert of on new $\mathrm{age}_{;}^{4}$ o renewed belief in the dignity of man and the importence of his actions and abilities instead of exclusive belief in external influences such es fote or divine intervention; ${ }^{5}$ a new love of learning inspired by the clossics, which wes followed by o drive to surpass the accomplishments of the Ancients; o disregerd for the Scholesticism end rigid subject divisions of medieval universities, opting instead for a broadening of knowledge to 
include new subjects and research methods; ${ }^{6}$ and, finally, a new sense of individualism stressing fame, yirtue, and civic accomplishment over piety and humility which inspired him to accomplish great deeds. ${ }^{7}$

In the enthusiesm of scholers to point out the olfferences between the Renalssence and medieval men, the peremeters of this discussion heve of ten been laid out in dramotic, block and white contrasts, when in reality the lines ore of ten blurred, os with any historical comperison. In an effort to demonstrate that the thoughts of the Renaissance man typified in many woys the beginning of the modern mind, same historiens heve exaggerated the contrasts between the medieval and Renaissence man. They have onnoyed Medievalists with their portralts of the medieval mon as childilke in his simplicity and unswerving in his loyalty to God and outhority. By contrast, the Renaissance man is sometimes depicted os a kind of superhumen or demigod for whom nothing is impossible. The Renoissence man is sometimes shown to have so much self-pride and worldliness thet he routinely defies God and outhority, relying only on his own judgement, somehow strengely divorced from the world of Christendom around him. His supposed complete dedication to secularism is praised by some authors as sophisticated and adult only becouse it reflects modern thinking. Indeed, Renaissance men are often depicted as so far ahead of their time thet they 
have nothing in common with the world eround them. ${ }^{8}$ This is not o very realistic portroyal of the intellectual climate of the Renaissance.

In truth, the men of tha Ranaissance fit neither of these two extremes. He wes not the men of childlike medieval foith nor the modern-thinking, sophisticated adult. He was more like on adolescent who sometimes displays adult-like cheracteristics and ot other times those of o child. Nor is this atypical of any oge of transition; man is the product of his past as much as the present, and no ege can be completely distinct from that which preceded and thet which followed it. The need to overciessify men of different eres comes from what is known 88 a Whig interpretation of history, in other words, a need to see progress in the development of man over time to something better (and naturally more like one's own age). This interpretation is flawed becouse men sheres common cheracteristics throughout the oges, and there is nothing better or worse obout modern men. The man of the Renaissance was still pious, still trusted euthority, and still tried to explain the unknown within the bounderles of the known before daring to soy that ail others beiore him heo been wrong. ${ }^{9}$

Scholars who have yentured their opinions on what constitutes a Renolssence men hove profiled men of all beckgrounds, from all parts of Europe. ${ }^{10}$ Eyeryone from Polish clerics to Spanish soldiers have been 
colled Humenists at some point. One group thet hes been ignored, however, is the explorers. It is odd that although much has been written about Itoly os the birthploce of a new oge, nothing has been said about it being the birthplace of the concept of the New World. Thomes Goldstein has written some very good works discussing the interreleted concepts of discovery and Humenism, but hes limitad himself to the speculotions of the Humenist geographers of Florence. " He had not discussed the men who picked up on these ideas and carried them into oction.

The typical discussion of explorers hos centered around biogrephical doto, nevigationel studies, and who deserves credit for discovering what. Going beyond this besic knowledge, it will be demonstrated in the course of this peper that the Itolien explorers had humenistic motives for their voyeges of discovery and that Humenism influenced how they interpreted what they found. This is evidenced by their research in the clossics while preparing for their yoyages, scientific and cortogrephical work, and search for new knowledge. The Itelien discoverers also possessed the typicel Reneissence desire to bring fome to themselves through greet and virtuous deeds, and to find a better understanding of man and his role in the world. I also wish to profile the world view of the Renaissence explorers of Italy by examining their writings and what was sald about them by their 
contemporeries. It will be demonstrated from this that the explorers were Humenists of an equal rank to those of fame in the history of ort, literature, philosophy, and government by virtue of their acedemic preperotion, accomplishments, and impact on intellectual history.

THE ITALIAN ERA OF DISCOVERY: 1492-1528

Before exomining the influence of Humenism on the Itelien discoverers it would first be useful to discuss the historicel context of the period in which their discoveries were made. In contrest to the usuel interpretetion of the Ero of Discovery es a phenomenon which occurred throughout Europe, on orgument cen be made for a distinct, earlier phose, which was wholly Itelien.

Scholers todey generally agree thet the discovery of Americe was not the gool of Columbus when he set seil for his first yoyoge in $1492 .^{12}$ Most scholars will ogree that instead he was looking for a shorter route to Asto than the Portuguese route around the Cepe of Good Hope. What is not generally known, however, is that Columbus led on entire generetion of Italion discoverers who shered his gool of salling west from Europe to reach Asio and would consequentiy try routes of their own. None of them found 0 passage through to Asio, but they did explore long stretches of coostline in 
what would soon be recognized es the New World. As a result, most of the shorelines and large rivers of the Atlantic seaboerd of the continents of North and South Amerlce were first discovered by Italiens.

Explorers of other nationalities came later to flll in the detalls of coestlines and to exploit the newly-found lands for their own purposes, but without exception those who first proposed the westword voyeges to Americe were Iteilans. The motivation behind these plens wos to gain more direct access to the markets of Asio by ovoiding the long overiand route and the price increeses of the Arob middlemen. Becouse Portugal was busy trying o route of its own, the Itolions sought patronage among each of Portugal's Europeen rivals. They promised to secure a quicker supply route to the spices and luxuries of the East, thereby bringing riches and fame for the netions which had hitherto been denied direct access to these highly volued goods.

By examining the origins of the plens to cross the Atlentic and the woy in which each of the Italion explorers sought to fulfill Columbus' dreom in his own way, we gain a clear picture of a distinct ero of Italian discovery Which is not apperent by simply looking at the lives of the discoverers individuelly. The dream of Columbus is clearly the common thread among explorers who will be exemined in this study. 
In many ways the Italien peninsula in the Renaissance was the perfect breeding ground for the tdeas which inspired the greet discoveries of the Itelians end others. A unique set of conditions existed in Italy in the fifteenth century which mode it the cultural, economic, and religious copital of the Horld despite the fact that it was still divided into seven mojor states and a smottering of smaller stotes and principalities.

A number of new arts and sciences were springing up which would provide Europe with the greotest new awakening of civilizotion since the foll of the Roman Empire. The list of Itelien contributions to the new age is stoggering. Among the new developments were Humenist philosophy and Iiterature, Renalssance ort, architecture and music. New sociol and politicel theory and proctices were being developed which would lay the foundations of the modern world. Economicelly, the Italiens beceme the leaders of o commerciel revolution by establishing the first means of mess production through speciolization of industry and the use of joint cepital. The quality and oppeal of Itolien menufoctured goods and the luxuries which Iteliens imported from the East allowed them to establish Europe's first network of internationel trede, benking, and currency exchenge. 
The most importent development for our present study, however, Was the creation of a new school of cortography which proved to be on importent forerunner of the Scientific Revolution beceuse of its use of what would later be celled the empirical method. ${ }^{13}$ The Itelien cartographers added to thair bese of geographical knowledge new Informetion geined by observation and experimentation. They were able to update their maps constontly, rather then rely strictly upon the geographfcal opinions of the Ancients. ${ }^{14}$ As with the Humenist scholars in literoture, the geogrophers begen collecting maps from everywhere and Improving their own products until they were the finest to be found in Europe. They in turn used this knowledge to formulate further geographical hypotheses, the most important of which, we shall see, being that of the possibility of reaching the Eest by solling west. The Italians originally hed - monopoly oyer trade with the Eest which others sought to bypass by finding o route of their own. Itolien dominence of trode with the Arabs in the Leyent for goods brought from the Eest evolyed from thair role in leeding and transporting Cruseders to the Holy Land in the Middle Ages. Since the most importent cities in the Italian trade network were also great naval powers, it is only natural that the cities with eccess to ports (Venice, Genoe, and Florence, which used Pisa and Piombino), would be the 
homes of the Itolian explorers. The great seaforing and commerciol reputations of these cities would open many doors for the Italien explorers as they sought potronege in foreign lands. Furthermore, the ideas of the Itelien Reneissence were exported along with their trade goods, and did much to prepare the woy for their overtures.

Even before the Renaissence, travel had long been a part of the tradition of the Italien peninsule. Ever since the days of Marco Polo Itelien merchents and clerics hod been iraveling io litile-known perts of the Earth and reporting back on what they hed found. ${ }^{16}$ The impetus for exploretion ocross the Atlentic (which hed seemed impesseble to the Ancients) occurred when all the right foctors came together about the time of the Council of Florence in 1439 . While telks went on to try to raconclle the Romen Cotholic and Eastern Orthodox Churches, Florentine geographers took the opportunity to interview the curious-looking foreign visitors from the fringes of the known world as to the extent of their geographical knowledge. ${ }^{17}$ Paolo Toscanelli and others begen to combine these new bits of informotion with whot they had been studying in the preceding years since the revival of study of the Ancient Geographers Ptolemy and Strabo. 
In typicol humanist foshion, they were willing to braek with medieval authoriterientsm and substitute newly-obtained informotion to reform their ideas obout oreos such es Asio, where the Ancients had been Wrong ${ }^{1 B}$ Reelizing that the Ancients had besed their notions on limited experience and second hand observation at best, the Itelien cartographers chose to belleve those who hed claimed to actually heve been there insteed.

In the fourteenth century Itelian cartogrophers gained fame by producing a series of practical charts for navigating cosstlines colled "portoleni" beceuse of their usefulness for finding familier European ports. When the Itelians edded this procticel siant to their Improvements on the observations of the Ancients, a whole new concept in cortogrophy wos born: that of updating maps with better observotion and drawing skills. With this, geography moved from philosophical speculation to a precise science. $^{19}$

From the informal geographical discussions during the Council of Florence, which had nothing to do with the church business being conducted, many naw geographtcal notions bagen to toke stipe. Not mony of these idees eyer went beyond chenges in locelly-produced maps, but what begen to evolve in the mind of Toscanelli, we can be sure ot least, was the notion of solling west to reoch Asto. ${ }^{20}$ As with many other aspects of the Italian 
Renoissence, this was borne out of both necessity and creative genius. On the prectical side, the overiand routes which the Arobs used to bring in luxury goods from the East to the Levent were cut off by the edvance of the Turkish armies, ${ }^{21}$ and the Portuguese were making advences in shipbuilding which ollowed for seiling out on the open see for the first time. ${ }^{22}$

The creative genius of Toscenelli, which perheps makes him the most underroted of Renoissence men, was to determine that the actual distence botween Europe end Asie wes much shorter then the Ancients had believed (bosed on the new reports) and thot o western possoge might be conceivably mode. Speculation as to the possfbility of a western crossing probably occurred in the Middle Ages as well, but the distence wos considered too great and the ships too froil to make the crossing. Toscenelli did much to spread his findings, and wa know that at leost Columbus corresponded with him. ${ }^{23}$ Columbus did his best to gather evidence for this novel proposal and try it out. In fact, it became his life's pession. Through him the other Itelien explorers leerned of the idee end did their best to try out routes to the East of the1r own.

Itelien merchents and scholars begen to be interested in the idea for two reasons: first, because of their tradition of learning by observation which they perfected in the orts, ond second, their lust for sdventure and 
profit. ${ }^{24}$ The connection between merchents, petrons, and scholers is by no means o contrivence. Meny of the great men of the Renelssence carried on 0 number of these roles simulteneousiy or chenged from one role to the other with eese, os is perheps best exemplified by the cereer of Lorenzo the Megnificent. But beceuse of conditions in Itely itself, the explorers hed to seek petronage elsewhere. Once they found it, the Great Age of Discovery wos born.

Seyeral foctors contributed to the need for Iteliens to seek foreign aid to support their voyeges of discovery. First, the aconomy of the dey required that anyone who wished to pursue an endeavor which was radically different from the traditional occupational pursuits of his forefothers obtoin support from a powerful patron. This was as much true for the explorers in the Renaissance as it wos for the ortists, philosophers, and man of latters. ${ }^{25}$

Second, although the practice of merchant capitolism which hed been perfected by the Iteliens for their commercial exploits in Europe proved to be importent in providing ships, meni, end equipment for the discoverers, the Italion petrons and merchents were so busy with other enterprises that they had no time or money left for the explorers. Hence, the need to seek sponsorship from foreign cepitelists and petrons. ${ }^{26}$ 
The Itolien merchents had too much et stake in the stotus quo to want to invest heavily in anything which might upset it. ${ }^{27}$ They were eager to keep up with any news from the New World and occosionally invested in merchent yentures to exploit recent discoveries, but unfortunately spent most of their time end energy figuring out how to make money from the foolish excesses ${ }^{28}$ of others (who ropidly spent the gold obtoined from the New World) instead of going out and claiming lands for themselves.

Furthermore, in the face of internai siruggies, interstate rivalries, and the threat of foreign invasion, no one Itelian state was ever powerful enough to sponsor yoyeges of discovery of its own.

Itelian resources were stroined to the limit at the time of the beginning of the Great Age of Discovery and simply could not accommodate onything new. The Venetions overceme the loss of territory and subsequent payment of duties to the Turks only by extending their empire inland to include parts of Italy. They were soon to learn that the power struggles of the Itelian mainlend ceme at no little cost, howeyer. Their oyersees empire gradually fell away as they increasingly diverted their energies to defending their territories and allies in the Itolion stotes. As we sholl see later, when an opportunity came to them to join the race to explore and claim parts of the New Worid, they were forced to back out of negotiations 
for feer of reprisals from their larger European rivals. The Genoens continued their prosperity for a while by serving os the European distributors of Portuguese spice imports. They still cut a high shere of the profit, but the city-stote eventuelly suffered internal coiiapse due to economic decline and foreign pressures.

Meenwhile, the Florentines meneged to keep a competitive edge by monopolizing banking, pepal collections, international currency exchange, and loans to foreign monerchs. But ultimately, follures in these foreign investments coused their economic collepse es well. ${ }^{29}$ One by one the great finenciel powers of Italy declined, and the mercenerles and forelgn powers Which the city-states once brought in to fight their fights begen to realize that they were stronger than either side in the locel conflict.

Eventually, Italy's neighbors beceme so powerful that they could battle among themselves for control of Itely itself, thus ending Italian commercial domination once and for all end extinguishing all hopes towards Itelien unificetion. This beceme possible because France and Spein had unified earlier and could use the gold from the New world to build lerge ermies of conquest. Furthermore, although they had been economically backward and dependent on Italy for high quality goods, they began to develop domestic industries and fleets to rival those of Italy. 
Italy's actlye role in the development of the New World was limited to the individuel accomplishments of its discoverers beceuse of its political isolation and disunity during the Age of Discovery. ${ }^{30}$ Perhaps the greatest Irony of the Itelien Ere of Discovery wes that very little of the profits from these great yoyeges come to the explorers themselyes or their states of origin in Itely. Nearly every one of the expeditions wes a commercial failure, and additional yoyages become increasingly more difficuli to innence. None of the explorers died wesithy men, and no ltaltan state aver claimed a colony in the New World (though other small nations did). ${ }^{31}$

With the hundreds of sailors, scholars, and merchantmen from various Italien states who salled under the flags of other nations, it is not difficult to imegine how an Itelian empire in the New World might have been established had Italy been a united country at the time. Instead of this, we have the legacy of the Italian Renalssance and all that it has givan the World, of which the Italian Ero of Discovery was an important part.

At this point it would be useful to provide the reader with a brief summary of the cereers of the great Italian discoverers. He shall avoid the numerous controversies which surround the cereers and accomplishments of the discoverers and merely recount what is commonly accepted as being 
true. Should the reader hove further interest in these controversies, a number of professionel studies ore widely avollable which discuss the various possibilities.

Christopher Columbus (1451-1506) was a Genoen whose real nome wos Cristoforo Colombo. He began sailing at the ege of twelve and was involved in nevigation and mapmaking all of his life. He do not know for certein how meny royeges he made in preparation for the epic crossing of 1492, but nearly every destination known and unknown in the Atlantic at the time hes been suggested at one time or another. Columbus made four voyages to the New World for Spain (1492, 1493, 1498, and 1502). His voyages primerily centered eround the islends of the Caribbean, the eastern shores of Central Americe south of the Yucatan Peninsula, and the northern shores of South Americe. His primery accomplishment was opening up the Atlentic to exploration and permenent development by Europeens. As we shall see loter, he did not in a reel sense discover Americe.

Amerigo Vespucci (1454-1512) wos o Florentine with close connections to the ruling Medici family. He was well yersed in humanist philosophy, mopmaking, novigation and merchent skills. He suryeyed the coasts of South Americe for a pessege to Asio in places that Columbus and others had neglected. His principal yoyages were for Spain in 1499 and 
Portugal in 1501-1502. His most outstanding accomplishment was to reolize his discovery was on entirely new continent, not just a port of Asio. Appropriately, therefore, the New World is named ofter him.

The fother and son teem of John and Sebostion Cabot solled in a series of voyages for England in an attempt to reach Aslo by a northern route. John Cabot (1450-1498?) was o Genoan whose real name was Glovonni Caboto. He made two royeges to the New World, one in 1497 and another in 1490 . He either died ot see or died in obscurity upon his return because of his inability to substantiate the claims of hoving found Asio.

His son, however, went to the oree near Lobrador in 1509 and ofter having realized the error of his father's ways began the search for the Northwest Passage. Heving failed that, he was also instrumental in organizing an expedition to search for a Northeest Passege, but was not allowed to go along because by that time he was advanced in age. The Cabots led the way for future British explorers and established importent cloims for the later development of British North Americe.

Antonio Pigofetta (c. 1492 to 1534) is best remembered for his first-person account of Magellan's attempt to circumnovigate tha globe. He wes born in Vicenze, Italy, and was o pepel envoy to the Spenish of the time that he volunteered for the voyage. He entered the Order of the Knights of 
St. John on Molte upon his return. He was a typicel Renoissance merchant scholer and his talents as a men of letters were put to good use in his beautifully written account of Megellen's yoyege.

Although not discussed at length in this poper becouse so little is known about him, Antonio Pigofetta is importent beceuse he informed the other Italian explorers of the possibility of a southern pessege to Asio. This would chenge the focus of their yoyeges from north to south os word spread, and help them betier understand that the oreas that they had Initiehy discovered were probably not o part of Asio. Magellan's voyage was the one which finally proved that a western route could be used to reach Asia, but that it was neither as easy nor as short os the Italians had believed. Consequenily, through possible contact with Magellan himself, or by hearing of Pigafetto's occount, the Itelien discoverers begen to join the seerch for a shorter southern pessege.

Finelly, Giovanni Verrazzeno (1485?-1528) solled to survey the eostern coost of North Americo for o possible stroit opening to a possage to Asia. He probebly tried this route because he had not yet heard of the return of the survivors from Magellan's expedition. He was born in Venice but was a member of the florentine merchant colony in Lyons, France. He salled extensively for this group on commerciol ventures to the Levent and 
gathered information and maps everywhere that he went. He did not find the sought-for passage to Asio, but wos instrumental in leading the woy for further French exploration and colonization of North Americe. Towerds the end of his life he also conducted expeditions which searched for possoges through South and Central America, but did not succeed in either of these gools.

All of these men, in their own way, contrlbuted to our portralt of the Reneissance mon as discoverer. They were not merely adventurers, but men greatly influenced by the Humanism of their age. Becouse of their educotion and reseorch, they corried with them the idees and fresh outlook of the Renalssence towards the world. Specific aspects of the Renaissence men in each of the explorers will be pointed out as this survey continues. This will be done by exemining their acedemic preparotions and navigational occomplishments es reveoled in their journels, contemporary accounts, and in the works of their biographers.

In general, the explorers bosed their decisions on the gothering of evidence tempered by empiricel methods. Observation and experimentetion allowed them to be open-minded enough to question the encient euthorities when necessery. ${ }^{32}$ Eech of the Italian explorers was a student of the "Italian School of Cartography" in his own right and carried its ideas into 
his mathods of preperation and exploration. They also invented new instruments and techniques to meet and survey new conditions, insteed of just relying on what tradition soid must be true. ${ }^{33}$ 


\section{NOT:S}

'Jacob Burckhardt, The Civilization of the Renaissence in Italy, 5th 6d. (London: Phaidon Prass Ltd., 1937).

2 Germen Arcinieges, Americe in Europe: A History of the New World in Reverse (Sen Diego: Hercourt, Broce, Jovanovich, 1975), pp.76-77.

3 Wellace Ferguson, The Reneissance in Historical Thought: Five Centuries of interpretation (Combridge, Mass.: Houghton Mifflin, 1948), p. 2.

${ }^{4}$ Ibid., p. 4.

5 lbid.

6J. H. Plumb, gen. ed., The Pelicen History of Europeen Thought, 10 vols. (Hormondsworth, Middlesex, Englend: Penguin Books Ltd., 1978), vol. 3: From Humonism to Science: $1480-1700$, by Robert Mendrou, trans. Brian Pierce, pp. 42-46.

7 Burckhardt, part II, especially p. 81.

EFerguson, pp. 198-199.

9 lbid., ch. 9 in pessim.

${ }^{10}$ lbid.

11 See bibliography.

12 Somuel E. Morlson, Admiral of the Oceen See: A Life of Christopher Columbus (Boston: Little, Brown and Company, 1942), p. 54.

13 Thomos Goldstein, "Geogrophy in Fifteenth-Century Florence" in Merchants \& Scholors: Essays in the History of Exploration and Trade, John Porker ed. (Minneapolis: University of Minnesoto Press, 1965), p. 12.

14 Frederick J. Pohl, Amerigo Vespucci: Pilot Mojor (New York: Colombio University Press, 1944), p. 9.

15 Thomes Goldstein, "Florentine Humenism and the Vision of the New World" Actos do Congresso Internocional do Historio Dos Descobrimentos 4 (1961): 195-207 in passim.

${ }^{16}$ Goldstein, "Geography in Fifteenth-Century Florence", p. 18. 
17 Boies Penrose, Trovel and Discovery in the Renoissence, 1420-1620 (n.p.: Hervard University Press, 1952; reprint ed., New York: Atheneum, 1975), pp. 3-27 in passim.

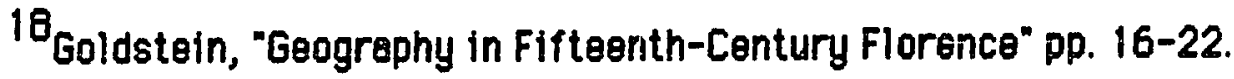
19 lbid.

${ }^{20}$ Geographers could no longer merely sit at their desks and speculate es to the nature of the globe. As Europeens begen to explore the for corners of the Earth in the following centuries, people demanded up-to-date mops to guide them. As mon begon to break out from the mentol confines of medieval geography, a passion developed to fill in the blanks on maps marked Terro incognita or with the names of mythicol londs. This need to know of the Renaissance man drove him to go to distant lands and find out for himself.

21 For more on this see Hirsch, Elizobeth Feist, The Discoveries and the Humenists" in Merchents \& Scholars: Essoys in the History of Exploration and Trode, John Parker ed. (MInneapolis: University of Minnesoto Press, 1965), p. 41.

21 |bid., p. 15.

22 Pohl, p. 7.

23 Morison, pp. 27-28.

24 Goldstein, "Geogrophy in Fifteenth-Century Florence" pp. 11- 16. ${ }^{25}$ Thomes Goldstein, The Role of the Itolian Merchent Class in Reneissence and Discoveries" Terree Incognitae 8(1976): 20.

26 Ibid., p. 22.

27 J. H. Parry, The Age of Reconnaissance: Discovery, Exploration and Settlement, 1450-1650 (New York: Praeger Publishers, 1965), p. 48.

28 ibid.

29 James Edward Gillesple, A History or Geogrophical Discovery: 1400-1800 (New York: Henry Holt and Company, 1933), pp. 74-75. 
${ }^{30}$ Parry, pp. 44-48 also see J.N. Stephens, The Foll of the Florentine Republic 1512-1530 (0xford: Clarendon Press, 1973), pD. 136-137.

31 Gillespie, pp. 65-66.

${ }^{32}$ Parry, p. 48.

${ }^{33}$ Hirsch, pp. 36-37. 


\section{CHAPTER II}

\section{CHRISTOPHER COLUMEUS}

To many people Columbus represents the very embodiment of discovery. He is in mony woys the consummote explorer beceuse he wos first and foremost a man of action. His accomplishments overshadow the storm of controyersy which already began to rise ahout him whila he liugd, and continued to braw for centurles after his death. Meny a scholar's Ilyelihood hes been besed upon crediting or discrediting Columbus in some woy or another, but as mistaken as he may or may not have been, he is nonotholess a men of great eccomplishment. So much so, in fect, that Jecob Burckherdt chose Columbus as his example of the Renolssence men whose desire for personel fame and fortune set him epert from the often unnemed heroes of the Middle Ages.'

Although medieval in much of his outlook and behovior as we shall 88e, Columbus did displey the cheracteristics of a Renelssence men. The foremost of these was the humanistic reseerch which he conducted in preperation for the yoyeges to Americe. His research wos as exhoustive as any Humanist scholar's. He scoured the clessics, the Bible, and the works of mediavel travellers for clues to what might lie to the west and how best to get there. As his son Ferdinand was quick to point out, Columbus drew from 
"the euthority of meny learned men who seld that one could sall wastwerd from the westem ond of Africe and Spain to the esstem end of Indie, and thet no greot seo lay botween." 2

He went on to cite the evidence of Aristotle, Ptolemy, Marinus, Strabo, Pliny and others that his iather's idea was worthy of Spain's support. The seme is repeatedly achoed in Columbus' letters to the

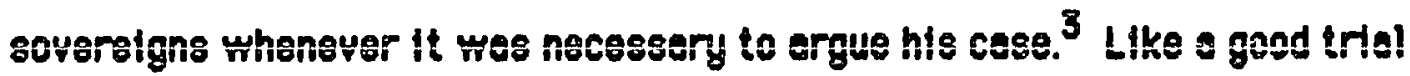
lawyer, he knew that everything was riding on how well-preparad he was, so he went to greot pains to find every screp of evidence he could. Many scholers hove written thorough onolyses of Columbus $80 u r c e s$ of inspirotion, 80 the reader will not be troubled with o lengthy discussion of them at this point. Suffice to sey that Columbus used every source ovolloble to him Colthough his interpretotions were sometimes questionable) in order to prove his case. 4

Not content to be o merely a medieval "ormchair troveller;" Columbus elso geined precticel knowiedge from his contemporeries. While working $8 s$ a mepmaker in Portugal he interviewed meny sallors to find out what they knew about previously uncherted erees to the west and south of Europe. He trovelled by see to the limits of the known world esking those he ceme in contect with what loy beyond before teking on such o dering venture 
as crossing the Atlentic. He trovelled north to England and Ireland, and possibly as far as lcelend to inquire after the findings of the Vikings. 5 trovalied south to the limits of the Porituguese discoveries in Africa where his visit to the gold-beering city of Le Mine below the equetor proved to him thet the southern hemisphere wes hebiteble and not merely o ploce of fire as legend hed $1 t^{6}$ He travelled east to the Levent to see for himself some of the areas mentioned by Merco Polo and thaulred about what lay beynond. While there Columbus might haye first gotten the passion for recapturing the Holy Land and winning lost souls which would dominate his rotionele for crossing the Atientic to reoch Asia. ${ }^{7}$ Finally, he went west to the Azores and Caneries, the forthest islends discovered by the Spanish and Portuguese in the Atlentic. He went there to follow up on rumors of voyeges further westword which had never returned, and to ovold meeting the seme fote he studied the winds and currents to determine the best possible route to the Indies.

His son Ferdinand related that Columbus even listened to stories of strange plants, carvings, canoes, and dead Indians who washed up on the western shores of these islands and compered them with descriptions of Asio mentioned by Ptolemy and others. He celled them "curtosities" however, and indiceted that his fother never mede them his main proof. 
Columbus' scholeriy ability was evidenced by his research in the clessics and certography, and by the persubstue letters he wrote to the regents of Europe petitioning for their support. Columbus' scholarly reputetion inspired his son Ferdinand to become o great Humenist in his own right. In preparation for writing his father's blogrephy, Ferdinend founded a library of his fother's books and pepers and added to it books which he collected from many perts of Europe. Ferdinand also accompented his father on some of his voyages. His expertise was also put to good use when Ferdinand served on o royol commission which corrected merine cherts, commissioned pilots, and decided the rival claims of Spain and Portugal over the Molucces. ${ }^{10}$

Columbus himself corresponded with the noted Humenist Peolo Toscenelli end was no doubt influenced by the latter's vision of trovelling westward to reach the Eest. ${ }^{11}$ Columbus also comperad notes with some of the best Humenist certogrophers of his day asking for copies of any books or meps he could get his hends on. He and his brother Bertholomew (Bertolomeo) set up a cartography shop while in Portugai which dio a brisk business beceuse of Genoe's fine reputation in mapmoking. A contemporory historlon, Andrés Bernoldez, ocknowledged that Columbus was "... very skilled in the art of cosmography and the mepping of the world. 12 
When defending his qualifications before the king and queen of Spoin Columbus argued,

I have had dealings and conversetion with learned men, priests, and laymen, Latins and Greeks, Jews and Moors, and meny others of other sects. I found Dur Lord yery fovorable to this my desire, and to further it He granted me the gift of knowledge. He mede me skilled in seamanship, equipped me abundantly with the sciences of astronomy, geometry, and arithmetic, and taught my mind and hand to draw this sphere and upon it the cities, rivers, mountains, islends, and ports, aech in its proper plece. ${ }^{13}$

As stated earlier, the process of Humenist certogrephy involyed both drowing from the works of accepted outhorities among the Ancients and adding on racent findings to make up-to-date, proctical soiling charts. The acquisition of this skill had two benefits for Columbus. First, he was exposed to the notions of the Anclents regarding the size of the earth and what ley beyond the known world. We know, for example, thet after corresponding with Toscenelli ebout the geogrephy of Ptolemy and others, Columbus began thinking about attempting o crossing of the Atlentic. Second, it gave him proctice in moking the new map form of globes or spheres which made compelling utsual aids whan trying to convince wary sovereigns to back his voyeges. 14 These methods were not lost on Columbus followers either; most of them would also employ maps as o source of income and as a way to gerner support for their voyages. 
Columbus' navigational skills also show that he was well-informad about some of the new adyences in science in his day. Columbus is credited with meny novigational firsts and even experimented with new nevigotional techniques on his voyeges. He is credited with being the first to discover magnatic declinetion and its yariations. He wes also the first to find the wind potterns and currents of the Western Atlentic end determine the courses for regular transatlent!c crnse!nge. He was the first Eurnpean to develop techniques to seil successfully through the unique hazards of the Sergesso See and the Ceribbean; the former with its olmost complete lock of winds, and the latter with its corol reefs, sudden storms and even hurricenes. ${ }^{15}$ Many later vessels would founder and be lost in these some orees. It is perticuloriy becouse of his skill in handling the previously unexpected dengers of the Carlbbeen thet Fray Bortoiomé de Los Ceses, a priest and scholer who hed travelled widely in the aree, declered, "I think Christopher Columbus was the most outstanding sellor in the world, versed like no other in the ert of nevigation. -16

What is most of ten cited as evidence of a Renatssence men is a broed bese of knowledge, and Columbus met this requirement easily. He scoured every book he could find in his day for knowledge perteining to his proposed voyege and ecquired meny skills along the way. As we have seen 
above, he knew about certography, astronomy, nevigation, mathematics, and In his lettars he of ten referred to the Bible and the clessics. In the letter clted above Columbus continues, "... I have made it my business to read all that hes baen written on geography, history, philosophy, and other sctences"17 All of these subjects ware in the standard curriculum of Humenist scholers. His son Ferdinand claimed that Columbus studied Latin ot tha Univarsity of Paylo, though wa have no record of his enrollment there. 18

Some scholers heve cited this as evidence of Columbus' shortcomings in the aree of acedemic preparation, but like many geniuses of the Ifolien Renoissence, Columbus' research and proposels were beyond the reach of the traditional curriculum of the universities. Instead, Columbus relied upon independent research and correspondence with other Humenist certogrephers to formulate his idees. ${ }^{19}$

Furthermore, he was known for his quelity of writing end penmenship. Froy Bertolome de Les Cases, o contemporory historien who had access to Columbus' pepers, confirms Columbus' learning and soid of Columbus' writing: "... He learned such calligrophy---1 saw his writing meny times---that he could have made o living by $1 t^{-20}$ His writing style for the most pert is that of a seamen cerafully recording nevigational 
details in his journal of the first voyege to the Caribbeen, but occesionally he waxes poetic in a style reminiscent of the Humanist poets when describing the beauty of it all. While expioring the isiend of Fernendine (Long Islend) he reminisced:

During this tima I walked among some traes, which wera tha most beautiful thing to see that I had ever seen, viewing as much verdure in so great o development as in the month of May in Andalusio, and all the trees were os different from ours as doy from night, and 80 the fruits, the herbege, the rocks, and all things. ${ }^{2 \hat{i}}$

He also told Andrés Bernbldez, the author of Historio de los Reyes

Cotólicos, with whom he stayed of ter returning from his second voyage, that in the Gulf of Cochinos in Cuba,

... there gushed forth two springs of water below it ... and when the tide was on the flood, the water was so cold and of such goodness and so sweet, that no better could be found in the world,... and all rested there on the grass by those springs amid the scent of the flowers which was marvellous, and the sweetness of the singing of the little birds, so meny and so delightful, and under the shade of those peims 80 toll and fair that it was a wonder to 880 it all. ${ }^{22}$

Upon arriving in the New world he also mode fascinating obseryations about the culture, religion, and society of its inhabitants. Ho wos surprised to not see the large cities and urben culture that Marco Polo hed described, but he falthfully recorded what he sew nonetheless. Of the first people he encountered he observed, They all went about es naked as 
their mothers bore them; and a women who was there wore no more clothes then the men. ${ }^{-23}$ And of their physical appeerance he commented,

Their hair wes straight, thick, and short.... They had hendsome features, spolled somewhat by their unpleasently broed foreheeds. They were of middle stature, well formed and sturdy, with ollve-colored skins that gove them the eppeerance of Cenery Islenders or sunburned peesents. Some were painted bleck, others white, ond still others red; some peinted only the face, others the Whole body, and others only the eyes or nose. 24

He goes on to descrlbe their culture, They had no erms like ours, nor knew thereof; for when the Chrlstions showed them a naked sword they foolishly grasped it by the blade and cut themselves. ${ }^{-25} \mathrm{He}$ also describes their weepons, conoes, and the lack of lerge onimals, enemies, or permenent houses. Columbus noted that the natives had o fascination with oll things Europeen beceuse they belleved that Columbus and his men were from Heoven. And so it is for every plece that Columbus visits; he records so much detall and corefully controsts the culturel differences of each group so well that some scholers heve suggested that Columbus was the first cultural enthropologist for the Americes. ${ }^{26}$

Columbus' willingness to go beyond a mere book knowledge of distent lends and explore them himself distinguishes him from medieval scholars. His preperetory, information-gathering journeys, petitions to the royel houses of Europe for support, the four Atlentic crossings, and 
exploration of a yest area of the Naw World gave him a vary cosmopoliten outlook.

This wes not much different from the merchent-scholers of his Italtan homeland becouse he had a keen aye for o way to tum a profit from his discovertes. The joumbl of his yoyage and his latters are full of detailed observations of what gold, spices end other commodities might be ratumed from the newfound lends and how inclined the netlyes might be to help extroct them. For exemple, Columbus speculotes about the first Notive Americens that he sees: They ought to be good servents and of good skill, for I see that they repeot very quickly whotever was sald to them. ${ }^{27}$ And later Les Cases quotes Columbus: ".. Nothing was lecking but to know the lenguege and to give them orders, beceuse every order thet wos given to them they would obey without opposition. 28

The Influence of Merco Polo on Columbus in this respect is very clear beceuse meny perts of his writings sound exectly like what Polo inight have sald, had he been describing the same ereas. Like Polo, Columbus comments on the evellobility of naturol resources, the relative friendliness or militery potentiol of netives, faclitities which would serve well for ports or ship building end many other bits of information which were no doubt Included for the benerit of future traders in the region. 
Both men ceme from o merchent famlly and wrote with mercentlle matters in mind. Columbus raad Polo's book, took datalled notes on it, and even took it with him on the yoyages. ${ }^{29}$ At times Columbus comments on the commodities which Polo seid should be at a given locetion; unfortunetely he wes nowhere near the pleces Polo was talking about and was often wrong in matching his findings with the identification of plants, animals and minerals which Polo described.

Although Columbus was influenced by humanism in many ways, he still retained several medieval cheracteristics. He wes in fact a transitionel figure between the Reneissence and medieval men.

Christopher Columbus had one foot in the medieval world and one in the modern. . . . Columbus' theoretical opproech to philosophy, theology, and certain scientific concepts places him firmly in the Middle Ages, but his overwhelming scientific curlosity, his bent for investigetion, his interest in the netural world, and his ablitty to eccept focts hitherto unknown moke him o men of the Renaissence. ${ }^{30}$

To the modern observer, the mind-set of Columbus is full of contradictions. Perhops this is why the list of his blographers is seemingly andless and the historiography of his anploits contoins books which describe him os everything renging from soint to fool. ${ }^{31}$ 
The achievement of Christopher Columbus undeniably made a great contribution to the amergence of the modarn age and placed him firmly among the great men of the Renaissance. Like them, he had been stimulated by the recovery of ancient learning into looking with new curiosity of the world around him and in speculating on its limits. At the seme time he was conservative in his besic outlook, 80 that, peradoxically, the discoverer of the new worid continugd to the end of his coreer to drow orguments and Ideas from the conyentional works of medieval cosmogrephers. ${ }^{32}$

Upon closer axamination we se日, then, that Columbus was in fact a transitional figure between the medieval and Renaissence men in much the some way as Dante has been portrayed as a transitional figure for literature. Like Dente, Columbus' desire to show men a clearer vision of the Gospel was foremost in his life work (while converting the lost is only given token mention by the other discoverers). Reeching remote and forgotten Christion ollies (such as the kingdom of Prester John or the Christiens in the Mongol court mentioned by Marco Polo) or the possibility of converting new and unknown peoples suggested by the Ancients wos oimost os important to him os finding Asio. 
Always before Columbus' mind were the words of Senece in Medea: -An oge will come ofter many years when the 0ceen will loose the chains of things, and a huge land lie revealed; when Tethys will disclose new worlds and Thule no more be the ultimate." 33 Like many others of his time, Coiumbus probobiy looked forword to repiacing the vast numbers of peopie lost to Christienity by the advances of Islam. Inspired by Marco Polo's descriptions of the relative receptivitig of the citizens of the Mongol Empire to Christienity, Columbus probebly hoped to convert the people that he hed found on whot he thought were the eestern shores of Asia to create or strengthen an eastern challenge to Islem.

Columbus frequently commented on the religious disposition of the Notive Americens he encountered ${ }^{34}$ and their epperent receptivity to conversion. He reasoned, "I believe that thay would aesily be mode Christians, beceuse it seemed to me thet they belonged to no religion. ${ }^{35}$ Later he said, "I don't recognize in them any religion, and I believe that very promptly they wouid turn Christiens, for they are of very good understanding. ${ }^{-36}$ Columbus' careful religious observences, piety and model Christien behevior are commented upon by all his favorable blographers, 37 and throughout his writings he portroys himself as a men celled by God to accomplish his quest. ${ }^{38}$ 
In a letter to the king and queen of Spoin upon his roturn from the third yoyege to Americe Coiumbus decleres, "Our Lord mede me the messenger of end showed me the way to the new Heoven and sarth. ${ }^{39}$ This doubtlessly pleyed en importent role in convincing the highly-raligious Queen lsebelle to support his mission. Censcious of her role in the recent crusede-like actions of uniting Spain end driving out the infidels, Columbus sought to persuede leabelle that his missinn would bring countless milltons more under the rule of Christendom. He deliberately reminds her of this foct when in the above-mentioned lotter he seys, "Incredulity struck everyone except our lady the Queen, who was enlightened and made to Inherit it all as His beloved doughter; I went to take possession of this in her royal neme." ${ }^{40}$ At another time Columbus even stated that he Wonted all the profits from his venture to fund the Crusades in the Holy Lend. 41

This cruseder mentality identifies him firmly with the mind-set of the Middle Ages. Thoroughly lacking from his writings are ony troces of Christion Humanism common among Italien scholers of his day. ${ }^{42}$ The dignity of men or e new outlook towerds God are nowhere to be found. Nor does Columbus epply the new techniques of textual criticlem to the portions of Scripture which he draws upon for ayidence. Finally, he mekes no 
mention of his efforts being part of a new and distinct ere in history. He merely sees his afforts to conyert the Indiens os on entansion of the reign of Christendom oyer the reaims of Derkness. To him, his mission is o pert of the Great Commission and the efforts of the Crusedes. ${ }^{43}$ Moreover, elthough Columbus wes influenced by Toscenelli the Humenist, had gathered information on Atiantic winds and currents through his own observations, and consulted the letest maps, his main sources for the possibility of reaching Asia by seilling west were from ancient and medieval sources. His stubborn relience on Ptolemy, the Apocryphe, and the accounts of Merco Polo regerding the neture of the Asien coestline (even When what he found was in direct contradiction to them) tarnishes his humanist reputation and resembies the scholesticism of a medieval authoritarian. 44

Columbus attempted to find the shortest possible distence for the length of a degree of longitude and thus the circumference of the earth in order to make the Atlentic crossing seem more feesible. In so doing, however, he deliberotely ignored contradictory and more widely accepted estimates in a way which can be colled self-serving ot best, and unscientificolly suppressing evidence ot worst. Also, most Christion Humenists would heve rejected the use of the statement in the apocryphal 
book of 2 Esdras obout the earth being $6 / 7$ habitable land and only one pert weter, because the book of Esdras was not cenontzed or recognized by all the Church Fathers. Columbus stubbornly clung to Esdras over aven Ptolemy or Aristotle becouse, "Esdras symbolized fath, the medieval belief that doctrine is inseperable from truth. ${ }^{445}$

These techniques shed doubt on his honest use of textuel criticism as a Humenist. Perheps Columbus felt strongly enough that the ends justiffed the means on this motter to Ignore his scruples in order to better persuede his supporters. At any rate, the effort backfired when the Royal Commission appointed by Spain to study Columbus' proposal found the onclent and Church sources which contradicted Columbus' and proceeded to pick his arguments epert point by point. ${ }^{46}$

This only succeeded in deloying Columbus' deperture considerably. Nor was that the end of it; loter these some orguments would reappear in the trials resulting from Columbus' dispute with the Crown regerding his shere of the returns from his ventures. ${ }^{47}$ Some of the unfoir accusetions ogoinst Columbus about whether he really wos the first to discover Americo and what o poor job he did administering its first colonies have served as fodder for his detractors' blogrophies from the time of the triel to this doy. 48 
Columbus' most medieval tratt, by far, wos insisting to his dying dey that he had found Asta despite all proofs against it. ${ }^{49}$ when faced with evidence to the contrary, every other discoverer eventually abandoned his belief that what he had discovered was Asio, but not Columbus. A true Renaissence men would heve revised his concept of the truth after having found evidence contrary to the Ancients opinions. This prectice wes ot the heart of the methods of Humanist cartography in which the explorers had all been schooled. Columbus, however, stubbornly trled to rearrange the fects to fit his preconceived notions of whet the Ancients had sald he should find, regerdless of how ridiculous or impossible this became.

In his first royage he found only islands, but he insisted that the islends were the Indies and that the inhebitants must be Indiens (thereby creating whot is perheps the longest running misnomer in history).

Perplexed by not finding what he knew must be at these latitudes, he desperately searched for screps of evidence to prove that he had found Asio. He brought back with him plant somples, the natives themselves, and a little gold es proor. 50

He returned to Spain quickly to meke his discovery known, insisting thot the lend of the Great Khen was very near what he had seen. From the very beginning some doubted his proof, however. 51 Had he continued just o 
little forther he yould have seen that he was nowhere near the places that Polo had described. The netiyes had told him that they had never heard of these places, but he disregarded thair opinions. Insteed, he brought himseif and others much misery by hoving to return to the Indies over and over again (with increesing difficulty in gaining support) to try to substantiate his cioims. ${ }^{52}$

On his second yougege, Columbus lended on the island of Cubs, but he insisted that it was an extension of the Asian moiniend. Columbus was convinced that he had reached the Golden Chersoriese (the Malay Peninsula), which Merco Polo had described. His stubbornness kept him from doing such - simple thing as circumnovigating Cubo (though the natives had told him that it was an island $)^{53}$ because he wanted to continue on to find the straits which would allow him to pess westward to Indie. Had he merely turned north from Hispentole, he would have discoyered that North Americe was not the Asian Moinlond. In foct, he made his crew swear upon poin of death that Cube wes not an islend in order to preyent anyone from contradicting his ciaims before the Spanish Court. 54

In his further voyoges he explored the eestern coest of Centrol Americe and the northern coest of South Americe, but when he could not find Japan, Chine, or the pessege to Indie which Polo hed described, the 
cracks in his arguments began to widen. On the third voyage, Columbus discovered a mainland to the south of his previous findings. Unwilling to revise his cosmology to fit this anomaly, he explained the geographical inconsistency as the mythical land of the Terrestrial Poradise.

When one considers that Columbus' journol is free from the typical mediaval trevelogua's accounts of mythicel beests and strangely formed men, it is hard to belleve thet he would so readly substitute the founteins of the Gorden of Eden for on unexploined fresh woter source in the Gulf of Pario. If seems that Columbus himself began to hove doubts when he referred to this land as a New World, but kept within religious orthodoxy by not distinguishing it as o new continent or lend not mentioned by the Bible or the Ancients. By going with the Terrestrial Poradise theory, Columbus could explain away this oree and the other islands he had found as an onomoly to the orees of the Asien coestline mentioned by Polo and Ptolemy and still press on towerds the passege to India. ${ }^{55}$

On the fourth voyege he solled olong the coest of Central Americe, believing that he wes following the Maley Peninsule to the Strait. He never found it, but returned home saying that he had not gone for enough and hed given up only because of the poor condition of his ships. Many authors have speculated whether Columbus knew by this point that he had not reeched 
Asie end was considering the possibility of a new world. Any private doubts he mey have had, he kept to himself however, beceuse he reiumed to Spain to try to convince the Crown thet he was close to Aslo before his enemies could do otherwise. ${ }^{56}$ By now, however, the wary Spenish had become like the villagers in the foble who had grown tired of heering the boy cry wolf and refused to listen to him ony more. They even rejected a request by his son Ferdinend to canduct a yoyege of exploration in $15 ! 1 .^{57}$ Ferdinand would have to find his own claim to fame as a writer and maritime advisor.

Columbus hed to leave it to other Spentsh explorers to fill out the detalls of the coestlines and interiors of the lands bordering the Ceribbean. At first the Spenish continued to call the new lands the Indies, but the circumnavigation of the globe by the Megellen Expedition of 1519-1522 confirmed that the New Worid was not a part of Aste. Once it was clear to the Spanish thet the land wos merely an obstecle on the way to Asio and not Asto itself, they had to reeveluate their colonizotion policy. In the meantime others began to search for alternate routes to Asie. It is possible thot if Columbus had token a different course on his voyages, the true nature of the New World might have been known much earlier and Columbus would have gone down in a more fovorable light in history. 
In the end, the Spanish were diseppointed because Columbus was not able to dellyer on his promises. At first the Crown begrudged his support, then ignored him, and finaliy began to toke legal action to deny him the titles, rights and privileges which had been granted to him earlier. What begen es a dispute over the slusiveness of Columbus' proof for his findings, beceme in time en obsession with making the colonies pay dividends worth ell of the effort expended. Like any other business investment, the heckers of Columbus could not be expected to take loss after loss with no tangible returns.

Nor were the early settlers happy to be in the New World. It should be remembered that the first colony in Americe wos hardly voluntary; it was a military garrison to protect whot was found. Its members were foced with many hardships, including disease, cannibel attecks, hurricanes, and shortege of supplies. And even if one did survive, there was no immediate promise of fome or fortune. ${ }^{58}$ There is little wonder that the New Worid attrocted few settlers until Cortés and Pizerro brought Spain gold through conquest and plunder. Perhaps this Spenish sense of initiel disappointment with the discoveries of Columbus accounts for their brutelity in conquering ond ensloving the natives of the New World. ${ }^{59}$ 
Nonetheless, Columbus' deeds served as an inspiration to many explorers who ceme after him. As we shall see later, all of the other Italian explorers were initially influenced by his notion of selling west to reach the East; they merely differed in their proposed routes and interpretation of what they found. Likewise, a group of men which servad under Columbus went on to further explore the New World under the Spanish. 60 


\section{Notas}

1 Jecob Burckherdt, The Civilization of the Reneissence in Italy, 5th ed. (London: Phaidon Press Ltd., 1937), p. 84.

${ }^{2}$ Hernendo Colón (Ferdinend Columbus), The Life of the Admiral Christopher Columbus, trans. Benjemin Keen (New Brunswick, New Jersey: Rutgers University Press, 1959), D. 15.

${ }^{3}$ See Journals and other Documents on the Life and Voyeges of Christopher Columbus, trans. and ed. by Samuel Eliot Morison (New York: The Heritage Press, 1963).

${ }^{4}$ See G.R. Crone, The Oiscovery of Americe (New York: Weybright \& Tolley, 1969).

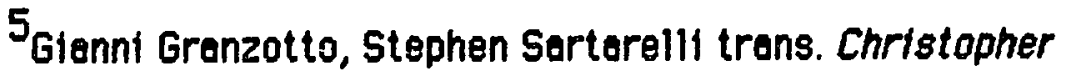
Columbus (Garden City, New York: Doubleday \& Co.1985), pp. 36-38.

6Ibid., pp. 46-47.

7 Ibid., pp. 26-28.

8 Ibid., pp. 44-45.

${ }^{9}$ Ferdinand Columbus, pD. 23-28.

${ }^{10}$ Ferdinend Columbus, introduction in pessim.

$11_{\text {Ser above, p. } 8 .}$

12 As cited in Samuel E. Morison, Admiral of the Oceen Seo: A Life of Christopher Columbus (Boston: Little, Brown and Compeny), 1942), p. 35.

${ }^{13}$ As cited in a letter to the king and queen of Spain in Ferdinand Columbus, p. 10.

14 Thomes Goldstein, "15th Century Geogrophy Against the Beckground of Medieval Science", peper presented ot the 4th ennual meeting of the Society for the History of Discoveries, Salem, Mass., 13-14 November, 1964. (Typewritten), p. 5; also Granzotto, p. 49. 
15 Roberto Almagio, L'Opere del Genio Itoliono All'Estero

vol. 1: Gli Itoliont: I Primi Esplorotori Dell'Americo IThe Itolions: The First Explorers of Americal (Rome: Lo Libreria Dello Stato, 1937), p. 377.

${ }^{16}$ Bertolomé de Les Ceses, History of the Indies, Andree Collord, trons. and ed. (New York: Harper \& Row. 1971), p. 17.

17 Ferdinend Columbus, p. 10.

18 Morison, Admiral of the Ocean Sed, p. 15.

${ }^{19}$ Grenzotto, p. 54. Also, Semuel Morison, for oll of his praise of Columbus in Admiral of the Ocean Sea and other writings, surprisingly downplays Columbus' educetion. He also controdicts himself by stoting that Columbus' writings are unspectacular seamon's notes on one occesion (in the introduction to his Journel and other Documents of Columbus) and idyllic on another (in Admiral of the Oceen 58a, his blography of Columbus).

${ }^{20}$ Bartolomé de Los Coses, p.15.

21 Morison, Joumals and other Documents, p. 73.

22 Morison, Admiral of the Oceen Sea, p. 459.

23 Fordinand Columbus, p. 60.

24 ibid.

25 Ibid., p. 61.

${ }^{26}$ Alfred W. Crosby Jr., The Columbion Exchenge (Westport, Co.:

Greenwood Press, 1972), pp. 3-6.

27 Morison, Journels ond other Documents, p. 65.

28 Ibid., p. 129

${ }^{29}$ Granzot to, p. 39.

30 Emilio Toyioni, Christopher Columbus: The Grand Design (London: Ortis Publishing Ltd., 1985), pp.17-18.

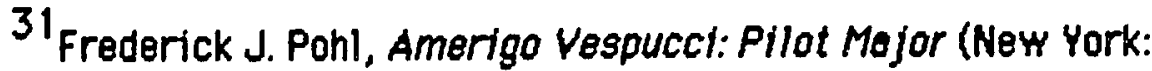
Morningside Heights: Columbia University Press, 1944), p. 11, also see Henry Vignaud, The Columbion Trodition (Oxford: Clere Publishing Co., 1920) and 
the endnotes of chepters 1-8 in Samuel Morison's The Europeen Discovery of America: The Southern Voyoges: 1492-1616 (New York: Oxford University Press, 1974).

\section{${ }^{32}$ G. R. Crone, p. 1.}

${ }^{33}$ As cited in Morison, The Europeen Discovery of Americe: The Southern Voyeges, p. 27.

${ }^{34}$ For the best occount see Ferdinand Columbus, ch. 62.

35 Morison, Jourmals and other Documents, p. 65.

36 Ibid., p. 72.

37 which isn't to say that there aren't uniavorable blogrephers. For more information see annotated bibliography following ch. 1 of Morison's The European Discovery of America: The Southern Voyages, or "Medio Siglo De Estudios Colombinos" Anuerio de Estudios Amertcanos 38 (1981): 1-24 for an up-to-date historiography of the controversies surrounding Columbus.

38 Morison, Admiral of the Oceen Sea, pp. 5-6.

39 Las Cosos, p. 70.

40 ibid.

41 John Addington Symonds, The Renaissance in Italy: The Revival of Learning (London: Smith, Elder \& Co. New York: Cherles Scribner's \& Sons, 1906), p. 15.

42 Although this may be more in keeping with the Sponish humanism of the Court.

${ }^{43}$ Symonds, p. 14.

${ }^{44}$ Poul Herrmenn, The Great Age of Discovery (Naw York: Herper \& Brothers Publishers, 1958), pp.15-21.

45 Granzotto, p. 56.

46 Ibid., pp. 78-83.

47 Both Las Casas and Ferdinand Columbus ot tempted to refute the claims against Columbus in the early chapters of their works, but their orguments hed little impact on public opinion because they were not published untll after their desths. 
48 Morison's Journel and other Documents of Columbus conteins most of the testimonies against Columbus by those who seryed under him. For assays on some of the eorly end/or contemporary blogrephers who attempted to discredit Columbus see Columbus, Cortes, and gther Essays, Remon Iglesie ed. (Berkeley: University of Celifornie Press, 1969).

${ }^{49}$ Edmundo 0'Gormen, The Invention of Americe: An Inquiry into the Historical Nature of the New World and the Meaning of Its History (Westport, Conn.: Greenwood Press, 1977), p. 59.

50 Ibid., pp. 77-78.

$51_{\text {Herrmann, pp. 9-10. }}$

${ }^{52}$ 0'Gorman, pp. $81-85$.

53 lbid., pp. 96-98.

54 Ibid., pp. 89-90.

55 Jbid., pp. 94-104.

${ }^{56}$ George E. Nunn, The Geogrephicel Conceptions of Columbus: $A$

Critical Consideration of Four Problems, Americen Geogrophical Society, Research Series no. 14 (New York: American Geographical Soclety, 1929), . Ch. 3; also Granzotto, p. 279.

57 Iglesio, p. 233.

58

O'Gorman, pp. 90-91.

59 James A. Williomson with cartography of the voyoges by R. A. Skelton, The Cabot Voyages and Bristol Discovery under Henry VII (Glasgow: Robert Mac Lehose \& Co. Ltd. The University of Combridge Press for the Hokluyt Society, 1962), p. 76.

${ }^{60}$ See Washington Irving, Voyages and Discoverles of the Companions of Columbus (New York: Frederick Unger, 1956), or Somuel Morison's The European Discovery of America: The Southern Voyages $1492-1616$. 


\section{CHAPTER III}

\section{AMERIGO VESPUCCI}

The moin torchbeorer of the dreom of Columbus wos Amerigo Vespucci. He begen his exploring cereer under Alonso de Ojede, en explorer for Spain end onetime lieutenent of Columbus, who decided to follow up on the at tempts of Columbus to find a strait which would allow pessage to India. Ojeda would fa!! and eyentual!y he denied nermission to return to the area by the Spanish Crown, but Vespucci would go on to other areas in search of thot some pursuit. More importent, Vespucci would eventuelly realize that the coestline he wos pessing by was o new continent, not merely an extension of Asio as Columbus had supposed.

It is fitting therefore that the iwo continents of the New World ore named after him and not Columbus beceuse Vespucci wos the first to realize that what he had discovered was not a part of Asio, rather a whole new world.' Undeunted by his early disappointments, he went on to copitolize on What he had found by seeking new routes to Asio, and experimenting with stellar observations, longitudinal meosurement, and techniques of navigation.

Whereos Columbus wos o transitional figure, Amerigo Vespucci represented the Renoissence men es explorer in every way. ${ }^{2}$ Vespucci's 
thorough humenist educetion influenced his religlous and philosophical views, cosmology, and scholerly objectivity in his approach to the unknown. Vespucct shered with Coiumbus the beckground of o non-university. humenist-besed educotion, ${ }^{3}$ but beceuse he wes brought up in Florence he had much stronger ties to the central figures of the Italian Renaissance than the Genoese Columbus. The Vespucci family had o long trodition of business and political leadership in Florence. Because of this they were trusted associates of the ruling Medicl family, the patrons and friends of many of the most importent Humenists of the dey. ${ }^{4}$

Amerigo's uncle Giorglo Antonio was a noted Humenist and book collector. He had studled Greek under Fllippo di Ser Ugolino Pierruzzi and acquired many ancient works for his personal library, which he eventually gave to the Medici family and the library of Sen Marco. As on important member of the Florentine Academy, he was a frlend of Mersillo Ficino, the chief scholor responsible for the reviyal of Platonism in Florence, os well os a friend of the noted Hellenists Francesco Castiglione and Doneto Acciaiuoili and other Humanists. This group studied the clessics, contemporary poetry and most important, were all followers of Tosconelli. They of ten met to discuss geogrophy and cosmography and were later kept abreest of Vespucci's discoveries through letters and maps which he sent to 
them. Giorglo Antonio had a great influence on his young nephew Amerigo, os did Antonio di Jecopo Lenfredini, a future director of the School of Florence, and Plero Soderini, the men who would become the only person ever elacted genfolonter of Florance for 11 fe, and whom Giorgio Antonio tought Letin, the classics, geography ond the physical sciences. ${ }^{5}$ As we shell see, Vespuccl corresponded with this group and the Medici family all of his life regerding his discoveries and geographicel theories.

Yespucel must haye learned his lessons woll becouse it was said of his certogrophy that the Sponish royalty " . . esteem it highly. ${ }^{\circ 6}$ in a letter to Lorenzo di Pier Frencesco de Medici in 1500 Vespucci reoffirms thot "men are not lacking in your city who understend the mop of the world, who moy perhops correct something in it; nevertheless, whotever is to be corrected, let them await my coming, since it may be that I shall successfully defand my mep. ${ }^{7}$ We can see, therefore, that by the time Vespucei hed become a famous explorer he wos not afroid to defend his mapmoking abllitles ogainst the followers of Toscenelli, for he relt thet he cotid demonstrate to them new areas of the world which they had not onticipated. He boldly stated that he could challenge the geographical experts because he had gone to the new lands and seen with his own eyes things which had contradicted the cosmographical notions of the Ancients. 
Vespucci probebly hed the most well-rounded humenist educetion of any explorer because of his uncle's trachings and the influence of his ossoclates. The influence of Giorgio Antonio's humenistic teachings on Amerigo can be seen from writings Amerigo made os o youth.

In a composition Amerigo wrote,

I hove always loved virtuous men and wished wall to all who follow the paths of virtue. ... I should like to tell you about a group of wise and learned young men I saw o few days ago, who in their conversetion revealed no other goal than the study of letters.... They have so aroused in me an ardor for such studies that I have put eside every other thought, to follow the path of virtue....

My father anxiously desires that I seek out and learn those things which may help me to win fame and honor... I shall conquer myself, and I shall behave in such a manner as to put aside from me all lewd pleasures and give true signs of virtue. ${ }^{8}$

And in emulation of his book-collecting uncle, young Vespucci concluded by discussing the collector's velue of a work of Plato that he had recently purchesed. $^{9}$

The influence of Amerigo's study of Petrorch can be seen here when one recells the fomous stotement of Petrerch: "Our sons formerly employed themselves in preparing such papers as might be useful to themseives or to their friends, releting to family affairs, business, or the wordy din of the courts. Now we are ell engeged in the same occupetion, and it is literally true, es Horace says, "learned or unlearned, we are all writing verses 
alike. ${ }^{-10}$ Late in life Vespucci would recall to Piero Soderint the happy days studying under Giorgio Antonio end lement, " ... hed it been possible to follow in his footsteps, "I should be quite o dffferent man todey', as

Potrerch soys. However that moy be, I am not ashemed of being what I om;

for I have olwoys token pleasure in virtue for its own seke and in scholarship. ${ }^{-11}$

Also, Vespucci had an awareness that he lived in a time which was different from the pest. The Humentst scholar, Lorenzo Velle, had sald:

But truly, as wretched as were those former times in which no learned man was to be found, so much the more this our age should be congratuleted, in which (if we exert ourselves a little more) I am confident that the languege of Rome will shortly grow stronger then the city itself, and with it all the disciplines will be restored. ${ }^{12}$

And Vespucci reflected in the some vein:

In doys past a man died who never awoke. He llyed as though in a perpetual sleep. He contributed nothing to phllosophy, he never engeged in a disputation or lald an argument before one who could answer him, or took pert in bottle, or occupled himself in trade. ${ }^{13}$

Finally, o glimpse of what would eventually become Amerigo's most important lire pursuit emerges in these same compositions:

Going back and forth to many distant lands, whereby talking and trading one can learn many things, not o few merchents have become wise and learned, something that cannot be explained in a few words. Moving obout and moking inquiries concerning the worid, whose limits we have not yet completely ascertoined, they can furnish valuable 
advice by word and association to those who come to them in search of counsel or clarificetion of some doubt concerning business and custom. 14

When the House of the Medic1 sent Vespucct to Spain, he earned enough money to buy his first mep. The beoutfful and highly occurate Volesco map of the Mediterronean was a finencial sacrifice for Vespucci at the time, but by insisting in the best quality ovailoble, Vespucci showed that his interest in nevigation was becoming more serious. ${ }^{15}$

While living in Seville he learned of the voyeges of discovery being conducted by Columbus at the time and bacome one of his finencial backers through o mutual business portner, Gianetto Bererdi. We do not have proof that Columbus and Vespucci actually met, but the common business and geogrephical interests of the two mede it likely. ${ }^{16}$ For example, Berordi mentions Vespucci as a trusted essociate in o portion of his will regarding - debt to be pold by Columbus. ${ }^{17}$ Parheps the two leorned men exchenged ideas regarding the nature of the globe and the teachings of Toscanelli.

Whetever the cese, when Vespucci decided to conduct yoyeges of his own shortly after beginning to hendle Columbus' business offairs, he had on eesier time gaining support for severol reasons. First, he spoke with more confidence and authority becouse of his better educotion. Second, he had o much less difficult time defending his proposols beceuse he did not try use 
- shorter meesurement of the length of a degree of longitude to make the earth seem smaller and his voyeges more easily completed. He wes also better known ond more occepted as a resident of Spein then Columbus. This wos pertly becouse of his business connections with the Meoici, his longtime residence in Seville, and because he had asked for Spanish petronage exclusively and avoided Columbus' mistake of going to Portugol first. Most important, however, is the foct thet Columbus had payed the way for voyoges of discovery by others beceuse of his ceaseless petitioning and explenation of his ideas to enyone who would listen. Finolly, although the Crown had promised exclusive rights of explorotion to Columbus, they begen to grent permission to other explorers like Vespucci becouse they did not make the some lorge demends for 0 shore of the wealth or political leadership of the lends discovered. ${ }^{10}$

Vespucci set soll under the Spanish flog on his first yoyage in May of 1499 with Alonso de 0jedo os the titular heod of the expedition. At first the expedition continued elong the northern coest of South Americe doing littie more than confirming whet Columbus had found. Yespucci soon showed his strong individualistic spirit, however, by splitting off from the main group and trying another route. He reaifized ofter a point that the route to Asia was not to be found by going directly west and therefore decided to 
turn beck and seek o different pessege by going south. He proceeded to explore the coest of what is now Brozil, and turned back only when he realized that he did not have the resources to go on any further. ${ }^{19}$

On his second royege in 1501 Vespucci switched to Portugal for support lergely becouse he knew that the areas he wished to explore would probably fall within Portugal's jurisdiction under the Treaty of Tordestlies. Interestingly, the Portuguese made no public announcement of the expedition becouse they were not anxious to publicize exploration so close to the egreed-upon Line of Demarcetion between the claims of Spain and those of Portugal. ${ }^{20}$

Vespucci returned to the coast of Brazil near the point where he had been before and then turned south. He was greotly encouraged when the coest soon began to turn westward becouse he thought that o pessege to the Far East might open up. His hope soon turned to disappointment when the coest began going southword once ogoin. He continued on, however, turning beck only when the severe storms and cold weather berred further travel towards the Antarctic Circle and his ships were beginning to show wear. Perhaps at this point he assumed that the coastline kept going southward until it joined the fobled continent of Terro Australis, which was presumed to go all the way around the world, join all of the continents in the Southern 
Hemisphere and thus enclose the one, great, Ocean Seo. He would have known enough to realize thet exploring eiong this much longer coastline Fould have been beyono his resources.

It is just as likely that Vespucci turned back becouse he faced the threat of mutiny on the pert of his crew. After all, they had travelled severol thousend miles by this point with no end to the coestline in sight. ${ }^{21}$ Later, at about this seme point, Megellan would successfully put down a mutiny ottempt and continue on to discover the long sought-after strait which now bears his nome. ${ }^{22}$ The threat of mutiny played an important role in the history of discovery. Columbus barely evoided one by finding land when he did, ${ }^{23}$ and by lying to the crew ebout the distence covered. ${ }^{24}$ Amerigo Vespucci and both John and Sebestion Cabot were forced to turn bock from their gools at vorious points becouse of complaints by the crew. Mutiny remeins the least studied aspect of the Great Age of Discovery, even though it was an importent factor in the success or follure of any given yoyage.

Although Vespucci did not accomplish his primary task of finding s route to Asio, his achievements on a practical level won him fame in his own day in Spain and abroad. Columbus, on the ather hand, wos lergely unknown outside of Spain because of the controversy over his claim to have 
found Asio end beceuse the Spenish wanted to keep any information regerding a new trade route s secret from other treding nations. Most occounts of Columbus' discovery were either published af ter his death or not published at all. In controst, the news of Vespucci's yoyoges wos spreed repidly beceuse they were known of in both Spein and Portugol and widely published in Itely. Vespucci's nevigationel skills provided him with gainful employment until the end of his life. ${ }^{25}$ In contrest, Columbus wes denied many of the rewards promised to him for opening up the Atiantic and finding lands to the west. His follure to deliver on the promises made about these some lends hounted him the rest of his life es he struggled in voin ottempts to substontiote his claims. ${ }^{26}$

We know from Vespucci's accounts that he was not olways in command of the voyeges, but whether the sponsoring notions decided to put someone of their own country in cherge to ovoid the leodership problems they were hoving with Columbus and his family or for other reasons, Vespucci's influence was olways poremount. He olways perticipated in the decision-moking for the group, and by the end of each voyage he was clearly in commend. Regardless of whom the sponsoring monarch hed put in charge originally, or whether that commend was nominal or not, Vespucci always surfoced as the octual leader by virtue of his ability. Becouse Vespucci 
wrote the accounts of his voyeges end the officielly eppointed lesders go unnamed, it is he who is given credit for these discoyeries.

Like Columbus, Yespuccl waxed poetic when describing the incredible beauty of the lands he found. In a leiter to Lorenzo di Pier Froncesco de Medicl written in 1502 he mused,

This land is very pleosing, full of en infinite number of very tall trees which never lose their leaves and throughout the yeer ere fragrant with the sweetest oromas and yield an endless supply of fruits, many of which are good to teste and conducive to bodily health. The fields produce many heros and flowers ond most delicious and wholesome roots. Sometimes I was so wonder-struck by the frogrant smells of the herbs and flowers and the sevor of the fruits and the roots that 1 fancied myself near the Terrestrial Paradise. ${ }^{27}$

The primevol beauty of the tropical rain forests must have conjured up youthful memories of the paintings of fantestical gardens by Sandro Botticelli and other Florentine peinters whom Vespucci knew. It is olso noteworthy thet Vespuccl was the first to mention here the healthfuiness of the rain forest's plants. How much more he would have been amazed hed he been aware of the great value of these plents to today's medicine? Following in the footsteps of Columbus in another woy, Vespucci gave us some of the first descriptions of the woy of life of the natives he found. He relotes, 
I strove a great deal to understend their conduct and customs. For twenty-seven days 1 ote and slept among them, and whot I leorned about them is as follows. Howing no lows or religious foith, they live according to nature. They understand nothing of the immortality of the soul. There is no possession of private property among them, for everything is in common. They have no bounderies of kingdom or province. They heve no king, nor do they obey anyone. Each one is his own mester. There is no administrotion of justice, which is unnecessary to them, becouse in their code no one rules. They live in communol dwellings, built in the foshion of very lerge cabins. For people who have no iron or indeed any metol, one con coll their cabins truly miroculous houses. ${ }^{28}$

In every locele thet Vespuccl visited he made careful and detalled observations about the culture, religion, dietary habits (including cannibalism), and relative friendliness or unfriendliness of the natives. He noted differences in the skin color, stature, sex relotions, dwellings, and language of the natives.

Vespucci went into much more detall than Columbus did when describing the culture of the notives. He still had the merchant's aye for $\theta$ good port or valuable local commodities, but he put for less emphesis on these things than Columbus did. Furthermore, he made o distinction between a voyage of discovery and a commerciol venture, and he brought bock items for trode only when it was required of him. ${ }^{29}$ He even made the distinction between discoverles (like his own) and rediscovery (like Vasco de Gama's) becouse de Goma was trovelling a route already mentioned 
by the Ancients. This tells us about the extent of Vespucci's preparation for his voyeges beceuse he could heve only made such a distinction if he had reed about the encient circumnevigation of Africe by the Phoeniciens. ${ }^{30}$ In another deperture from Columbus' nerrative, Vespucci ovoided specific references to things in Asia mentioned by Marco Polo and instead commented on the uniqueness of what he himself had found. He also stopped colling the people he found Indians after the first voyege; thereaf ter he merely referred to tham as natives. 31 This talls us that he was not under any great burden to prove he wos in Asio but wos willing to occept the possiblitity of a previously undiscovered land.

Unilike Columbus, Vespucci never tried to explain away things that contradicted the bounds of what was known. Instead, he openily challenged the opinions of the ancient geographer Strabo and others when personal experience proved them wrong. In o letter to Lorenzo di Pier Francesco de' Medici written in 1500 he boldly stotes,

It appears to me, most excellent Lorenzo, that by this voyoge of mine the opinion of the mojority of the philosophers is confuted, who ossert that no one con live in the Torrid Zone because of the greet heat, for in this voyage I found it to be the contrary. The air is fresher and more temperate in this region, and so many people are living in it that their numbers ore greater than those who live outside of it. Rationally, let it be said in a whisper, experience is certainly worth more then theory. ${ }^{32}$ 
In the seme challenging manner he steted leter in the seme letter, "It is soid that in the whole worid there ore not more then seventy-seven languages, but I declare that there are more than a thousand. I alone have heard more then forty. ${ }^{33}$ Dering to question end improve upon anciant outhorities is an unmistakable exomple of the thinking of a late Renalssence mon. Vespucci wos not content to merely imitete the Ancients or conform his idees to theirs. True to the ideals of the Florentine Renaissance, Vespucci wished to surpess them and accomplish greeter deeds of his own.

Moreover, his religion and phllosophy were more in keeping with those of the Itolian Renaissence becouse the primery drive for his discoveries wos the quest for knowledge, virtue, and fome, not a need to satisfy the great commission or stert o new crusede. In a version of the letter to Piero Soderinl of 1504 which eppeers in the contemporary wark on geography Cosmographioe Introductio, Vespucei, in typicel florentine fashion, recalled that the lure of fame and o desire to perform virtuous deeds celled him from the mundene world of business, ... I came to this country primerily es a merchent. ... But when I abserved the various changes of fortune, and sow how voin and fleeting riches ore ... I determined to abandon the business career and to devote oll my efforts to worthier and more enduring ends. And so I set obout visiting different parts of the world and seeing its many wonders. 34 
He made offorts to Christianize the natives just es his contemporeries did, but this wos not his primery purpose. In fact, such offorts are mentioned only once in all his writings. There is o decidedly more secular tone in Vespuccl's writings then in those of Columbus. He mentioned embarking on voyages of discovery to do God's will, but he also hoped to gain everlosting fame for himself.

Yespucci had the common Rensissence attitude that the best way to get closer to God wos to accomplish one's utmost and thereby achieve virtue, which is pleasing unto God. His ambition was ovident when he sald, In the endeevor to ascertain longitude I have lost much sleep, and have shortened my life ten years, but I hold it well worth the cost, becouse if I return in sefety from this voyege I hope to win fome throughout the ages. May God not escribe my ambition to arrogance! All my labor is consecrated to His holy service. ${ }^{35}$

Vespucci's humanism wos olso reflected in his cosmology. Like Columbus, Vespucci seid thet the lands he sow reminded him of the accounts of the Terrestriel Peredise, but thet is where he stopped. He merely seid that the lend seemed thet beautiful to him, he did not belleve that the Garden of Eden was o literal place on the globe. Columbus, on the other hend, wrote a lengthy argument claiming that Eden must haye been what he found neer the Gulf of Parlo to cover up contradictions between what he expected and what he found. 36 
In o menner reminiscent of the enclent geogrephers, Vespucci cerefully recorded the differences of one group from another when discussing the religion and culture of the notives. When recounting the beliefs of one group of netives he encountered, Vespucci epproeched the unexplainable and unfamiliar by relating their beliefs to contemporary and ancient schools of philosophy,

No one of this rece, os for as we saw, observed any religious law. They can not justly be called either Jews or Moors; ney they ore for worse than the Gentiles themselves or tha pagans, for we could not discover that they performed any secrifices nor that they had any speciol ploces or houses of worship. Since their life is so entirely given over to pleosure, I should style it Epicurean. 37

Vespucci also accepted the natives' nakedness and customs as derived from noture rather than out of sinfulness or lack of shame. ${ }^{38}$

Columbus and Vespucci may have viewed the world somewhat differently, but there was no conflict between the two of them regerding their cleims or discoveries. Among the more vain attempts of $80 \mathrm{me}$ scholers hes been that of trying to prove that there wos some kind of rivalry or enmity between Columbus and Vespucci during their lifetimes. They contend that Vespucci conspired to steal Columbus' glory by cloiming to be the first to discover Americe. ${ }^{39}$ Nothing could be further from the truth. In fact, Columbus had intimate business deolings with Vespucci; the 
two corresponded and were probably frlends. As we have seen, we have no conclusive evidence that they shared ideas about Toscanelli's geographicel concepts, but their mutual acquaintances and business dealings made it likely. Columbus, in a letter to his son deted Februory 5, 1505, confided that he trusted Vespucci implicitly.

i spoke with Amerigo Yaspucct, the bearar of this latter, who is going to court on matters relating to novigation. He always showed a desire to pleese $m e$, and is a very respectable man. Fortune has been adverse to him, os to many others. His labours hove not been so profitable to him as he might have expected. He leaves me with the desire to do me service, if it should be in his power. ${ }^{40}$

At ony rote, it wos not long of ter the return of Columbus from his second yoyege thet Vespucci decided to go beyond finencing yoyeges of discovery and conduct them himself. While on his voyages Vespucci mentioned Columbus by name and gave him credit for discovering several places. The only exception to this is thot Vespucci gove on earlier dote then Columbus for his exploration of the northern shore of the South Americen mainiand. He seid that the place wos already nemed Pario, however, and made no ottempt to directly claim credit for discovering it before Columbus. The inconsistency con either be exploined by the froilty of humon memory regarding dates and place names or by an error made by the 
trenslator or publisher. ${ }^{41}$ Nothing in the tone of eny of his accounts of the yoyage would indicate that Vespucci deliberately contradicted Columbus or tried to steal his glory.

The real reason historiens writing soon after the death of the two discoverers discredited Vespucci was that two widely published accounts of Vespucct's journeys, the Mundus Novus and the Cosmographiae Introductio, gave Vespucci credit for discovering Americe first, and made no mention of Columbus. Unfortunately, Vespucci had no knowledge of their publication or he probably would hove cleared up the motter. ${ }^{42}$ These documents provided the besis for centuries of historiogrephy which ot tempted to defome the cherecter of Vespueci on the false belief that he either purposely had the books published and suppressed word of Columbus' occomplishments, or did nothing to stop them for his own selfish pursuit of vainglory and profits. ${ }^{43}$

These two pubilished versions of Vespucci's travels also began the controversy over whether Americo is rightly nomed for Vespucci. ${ }^{44}$ The introduction to Cosmogrophioe Introductio procloimed: "... The fourth port of the earth, which, becouse Amerigo discovered it, we moy coll Amerige, the land of Amerigo, so to speok, or Americe." 45 It later explains the feminine ending of the name as necessary because all the other continents 
were nemed for women. 46 Thus the sirange explenetion for a continent which is named for a mon, but has a feminine name.

Americe is rightly-named becouse the true discoverer is the one who knows what he hes found. 47 vespucci's most important accomplishment wos realizing that the lands that he had discovered were not a part of Asia, but o whole new continent-- o new world. ${ }^{48}$ (He begen to realize this at some time during his second yoyage). Vespucci very cleverly offered as proof of this two observations: he deduced that the long coestlines that he pessed must heve been pert of a continentel landmess beceuse of the great volume of water of its huge rivers, and that the many large animals which he observed are not normally seen on islends. 49 This shows that the scientific teachings of Giorgio Antonio were put to proctical use by Amerigo during his voyeges of discovery, ond that like other Reneissence men, Vespucci wes well-versed in meny subjects.

The news of Vespucci's discovery of a new continent, and not just islands near Asia, did not reach Europe until a few years later, but the widespreed publicetion of his findings meant that most people heerd of Vespucci's discoveries and the conclusions drawn from them before thase of Columbus. In e tract celled Mundus Novus, besed on Vespucci's letters to the Medici, Vespucci said that he had found a new world: 
For none of our encestors had any knowledge of the countries we saw, nor any ideo whot they contained. Our knowledge goes for beyond theirs. Most of them believed that no mainiend existed south of the equator, that there were only endless stretches of see which they celled the Atlentic. And aven those who considered the existence of a continent possible soid that it must be uninhabitable. My royage has now proved this view erroneous. ${ }^{50}$

This news caused quite a stir, and the new medium of printing helped to moke Vespuccl's letters become "best-sellers" in Europe.

Meanwhile those of Columbus remained largely uniknown beceuse the Spenish wished to keep secret what they still hoped was o foster route to Asio. Unfortunately, os we shall see, this misled careless scholars of future generations aither to Ignore Columbus' accomplishments entirely or to try to vindicate him to such o degree as to portroy vespucci os an usurper and o froud. ${ }^{52}$

Besides being the first to recognize the New World for whet it wes, Vespucct also made important adyences in the science of navigation. Discontented with the rather hophazard way in which nayigation had been conducted below the equator by the Portuguese up to that time, he decided to try to find the pole ster for the Southern Hemisphere. He did not find it, but he did contribute significently to charting the brighter stars of the southern skies in such o woy as to be useful to future novigotors. ${ }^{53}$ Also, to evold the gross errors made by Spanish novigators in measuring 
longitude, he invented o new method of colculating the distance a ship covered by use of estronomical observation and mathematical calculation. The method in use ot the time was to rely on dead reckoning from flued points of deporture which were wall-known to the novigotors. This meant that they could determine latitude by opproximation, but were alwoys uncleer ebout longitude due to the leck of eccurote means of meesuring the speed and distence trevelled. ${ }^{54}$ This accounts for the hit and miss noture of early Spanish navigation and axplains why savaral axpeditions lesving from the seme place could all end up at rodically different destinations. 55

Vespucci's method of mathematical colculation proved to be the most precise method of determining longitude and distence end speed trovelled until the invention of the first reltable shipboerd clock in 1714 by John Herrison. Until that time Vespucei's method of ostronomical observation wes used widely. ${ }^{56} \mathrm{He}$ also celculated the circumference of the Earth remerkebly within two miles of the correct figure! 57

In recognition of his skills Vespucel was made Pllot Major, a special teaching post oppointed by the Spenish Crown to teach its navigators this method and the use of better maps and nevigationel tools. The document which eppointed Vespucci to the position describes the loss of life and property by untrained pilots until then and decleres that pilots: 
... shall be instructed and shall know what is necessery for them to know respecting the quadrant and astrolabe, in order that, by uniting theory with practice, they may be able to make goout use of theirin in the soid yoyoges made to the soid ports, ond, without such knowiedge, no one shall go in the soid ships as pilots, nor receive pey os pllots, nor mey the masters recelve them on boord ship, until they have first been examined by you, Amerigo Despuchi (sic), our Chief Pllot ....

... It is olso reported to us that there ore many charts, by different masters, on which are delineoted the lands ond islands of the Indies to us belonging, which by our order have recently been discouered, and that these charts differ very much from one another; os well in the routes as in the delineations of coosts, which moy cause much inconvenience. In order that there may be uniformity, it is our pleasure, and we order that there shall be made a general chert [Padron General], and that it moy be more accurate, we order our officers of the House of Contratacion at Seville that they shall assemble all the ablest pilots that are to be found in the country at the time, and that, in the presence of you, Amerigo Despuchi, our Chief Pilot, a padron of all the lands and islands of the indies that hove hitherto been discovered belonging to our kingdoms and lordships shall be made...58

Vespucci put his skills os a cartogrepher and navigator to good use and performed this losk well. This job provided him with anough intellectual satisfaction and finencial remuneration to keep him comforteble for the rest of his 11 re. 59

Yespucci's final contribution was the influence he had on his nephew, Glovannt. It is belleved that Giovennt accompented his uncle on some of his royeges because he was later oppointed to the seme distinguished post of Pilot Major for Spain in 1512, a position that one 
could not get without greot experience ot seo. We know for certein that he accompented Pedrories de Avilo as o pilot in the expedition to sattio the oree of Dorien in 1514. It was said at that time thet he had possession of his uncle's pepers, chorts, ond mops which mode his contribution very helpful to the precise navigation of the voyage. He also plcked up on his uncle's mapmoking skills as evidenced by o beoutiful moppemonde that is still extant (unlike his uncie's meps, unfortunately). ${ }^{60}$

The many accomplishments of Vespucci did not win him the fome one might imegine. A series of events related to the publication of his letters occurred about which Vespucct knew nothing. A number of his accounts would be bostardized, embellished upon, and translated and retranslated, resulting in changes that Vespuccl would hardly hove recognized. ${ }^{61}$ As a result, controversies have arisen os to whather he conducted two yoyeges of discovery or four, whether he preempted Columbus in the discovery of the northern coestline of South Americe, and whether some of his accounts were made up by Vespucci or forged by others. Some have even doubted whether Vespucci sailed at all or knew anything Bbout cosmography due to folse assumptions of Vespucci's desire for fome ot ony cost. 62 
Some of this confusion may have resulted from the fact that Vespucci planned to publish a book to replace and clarify the contradictions contained in his letters. In an undated letter to his friends in Florence defending those who disputed him he complained, "... you are filling me with vainglory by making me think that my letter is considered a great paper, when I dashed it off as one writes to an acquaintance. ${ }^{63}$ Unfortunately, however, the king of Spain never returned the advance copy to Vespucci to finish editing. Since then this book has been lost, and several overlapping and sometimes contradictory accounts of Vespucci's travels have been published, which are probably partly based on this book and partly on his letters. This unfortunate set of circumstances reminds one how often the historian's task is made more difficult by men's uni inished deeds or memoirs which are written in too much of a rush. Unfortunately most men are too busy in this life to make sure that the record is set straight for posterity. When discussing the lost works of the discoverers the Italian historian Roberto Almagia comments, "... the loss of this precious material, that would permit us to be able to more complete?y reconstruct the character and the work of these Great Ones, does not have to diminish the value of their contributions in our eyes." 64 
Most of the errors and controversies in the conflicting documents revolve around dates of yoyeges and precise measurements of locations Vespucci claimed to have visited. These kinds of errors probebly resulied from mistokes made by translators and copylsts. Since these have been dealt with extensively by other authors and are not directly relevant to our current theme, they will not be discussed ot this point. Vespucci's observations on nature and the culture of the natives he found are commen thread in all his writings and are largely undisputed, so they hove been quoted without reservation. Other references to the cheracter or claims of Vespucci are for the reader to evoluate for himself. The notes ot the end of this chapter provide ample information regarding the disputed voyeges and documents for one to investigote further if so desired.

Despite the controversies which haye marred his reputation, Vespucet is a key figure in the Age of Discovery beceuse of his meny contributions. He was instrumental in opening up the only route which would prove an ecceptoble possege to Asto, and was the first to declare his discoveries part of the New World. He wes a skilled cartographer, navigator, and observational astronomer. He was instrumentol in institutionalizing Spenish exploration by serving os the first Pilot Major, training and outfitting discoverers, and consolidating and refining maps to 
help lay the groundwork for the Spenish Empire in the New World. He was o keen observer of noture and culture and provided us with some of the best and earliest descriptions of South Americe and its inhebitants.

What's more, Vespuccl wos o child of the Florentine Renoissence. His humanist training and sentiments are ovident throughout his writings, and they hed a profound effect an his world view, religion and phllosaphy. He also showed the beginnings of what would soon be recognized as the empirical method when he doubted a priort essumptions or the opinlons of ancient authorities in the face of contradictory evidence. He took on importent step in the theoretical conceptualization of the New World by refusing to explain awoy exceptions to the cosmogrophy of the PtolomeicPolo tradition of the late Middle Ages. Insteed he revised his concept of the globe as new experiences and discoveries brought obout changes in his thinking. So it is that mopmakers have rightly used the name Americe because it was Amerigo Vespucci who first recognized it as a new world. 


\section{NOTES}

IFrederick J. Pohi, Amerigo Vespuccl: Pllot Mejor (New York: Morningside Heights: Columbio University Press, 1944), pp. 175-179.

2 Ibid., p. 12.

3 ibid., p. 18.

${ }^{4}$ Germán Arciniegos, Amerigo and the New Horld: The Life and Times of Amerigo Vespucci, Harriet de Onis trans. (New York: Alfred a. Knopf, 1955), ch. 3 in possim.

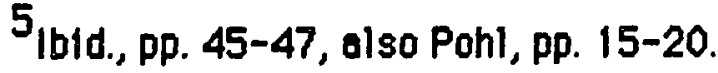

6 As cited by Pohl, p. 89.

7 Ibid.

$\theta_{\text {Arcinieges, p. } 41 .}$

9 Ibid.

${ }^{10}$ From Froncesco Petrarce, "The Men of Letters" as cited in The Portable Renaissance Reader, James Bruce Ross and Mary Martin McLaughlin eds. (New York: Penguin Books), 1981, p. 121.

${ }^{11}$ The Introduction to the Four Voyeges letter in the version of the Soderini Letter of 1504 as it appears in Martin Woldseemüller's, Cosmographiae Intraductio. March of America Facsimile Series, no. 2, Joseph Fischer and Franz von Wieser trans. (Ann Arbor: Uniyersity Microfilms inc., 1966), pp. 85-86.

12 From Lorenzo Valla's "The Glory of the Latin Language" as cited in The Portable Renaissonce Reader, p. 134.

13 Arciniegos, pp. 42-43.

14 Ibid., p. 43.

$15_{\text {Ibid., pp. 113-114. }}$

16 Ibid., pp. 103-104.

17 Pohl, pp. 43-44. 
18 Ibid., p. 43.

${ }^{19}$ Ibid., pp. 175-179.

20 See Pohl, pp. $91-105$ in peseim.

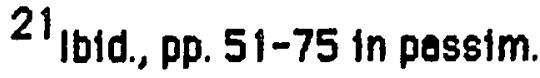

22 Ibid., pp. 106-125 in pessim.

23 Arciniegos, pp. 245-255.

24 Paul Herrmann, The Great Age of Dlscovery (New York: Harper \& Bros., 1958), p. 35.

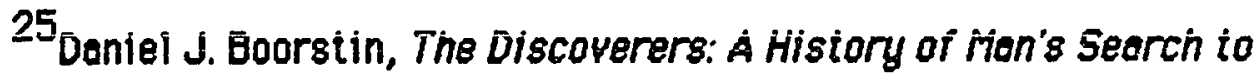
Know His World and Himself (New York: Random House Inc., 1983), p. 234.

26 Arciniegos, pp. 273-284.

27 Pohl, p. 132.

${ }^{28}$ Pohl, pp. 132-133.

29 Ibid., p. 135.

30 Ibid., p. 89.

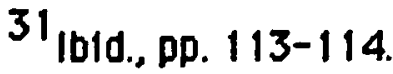

32 Pohl, p. 81.

33 Ibid., p. 86.

34 Ibid., p. 87.

$35_{\text {Pohl, p. } 127 .}$

$36_{\text {Pohl, p. } 113 .}$

${ }^{37}$ Four Voyeges version of the Soderint Letter of 1504 as it appears in Woldseemuller, Cosmographiae Introductio, p. 97.

${ }^{36}$ Frogmentary letter of Vespucci to his friends in Florence (c. 1502) as cited in Arciniegos, p. 237.

${ }^{39}$ This begen when Las Casas attempted to discredit Vespucci besed on incomplete information (see note 41 below), but became perticularly popular when nationalistic New World historians rallied oround American 
folk heroes in the last century, denouncing any rivals of Columbus. Again, had they carefully examined all of the sources and not just based their opinion on Las Casas' judgement, they would have seen no conflict between the claims of Columbus and Vespucci. As a result the historiographical reputation of Vespucci was severely tarnished and objective examination of the life of Vespuccl did not begin untii this century.

${ }^{40}$ As cited in Clements R. Markham ed. and trans. The Letters of Amerigo Vespucci and other Documents Illustrative of His Career (New York: Burt Franklin, reprint ed. n. d., originally published by Hakluyt Society), p. 57.

${ }^{41}$ Roberto Levillier claims in Americo Vespucio (Madrid: Ediciónes Cultura Hispanica, 1966), pp. 26-29, that the original Italian version of the account of this discovery calls the place Lariab which is an area in Mexico, nowhere near Columbus' discovery. He aiso says that the reason why Ferdinand Columbus never attacked Vespucci for usurping his father's claims is that he had an accurate copy of the Italian original, and saw no contradictions in the two dates and places of discovery. Levillier states that Las Casas was in error in calling Vespuccl a fraud because Las Casas' only copy of Vespucci's travels was an inaccurate Latin translation. He further states that this initial error was the beginning of the deluge of discredit unjustly heaped upon Vespucci since then.

${ }^{42}$ Stefan Zweig, Amerigo: A Comedy of Errors in History Andrew St. James trans. (New York: The Viking Press, 1952).

${ }^{43}$ Pohl, pp. 147-167 in passim.

44 See Edmundo O'Gorman, The Invention of America: An Inquiry into the Historical Nature of the New World and the Meaning of its History (Westport, Conn.: Greenwood Press, 1977) or Roberto Levillier, América, La Blen Llamada [Amerlca: The Well-Named Land], Z vols. (Buenos Aires: Editorial Guillermo Kraft Ltd., 1948).

45 Four Voyages version of the Soderini Letter of 1504 as it appears in Waldseemüller, Cosmographiae Introductio, p. 63.

46 Ibid., p. 70.

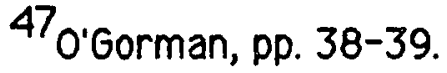

${ }^{48}$ Pohl, p. 140. 
${ }^{49}$ Pohl, p: 77 and p. 83 respectively.

50 As cited in Zweig, D. 40.

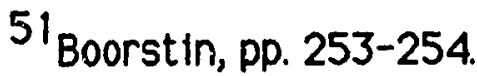

52 See below pp. 23-25 and Arciniegas, pp. 302-314.

53 Pohl, p. 125.

54 Ibid., pp. 48-49.

55 Herrmann, p. 32.

56 Pohl, pp. 62-68.

57 Ibid., p. 119.

${ }^{58}$ As cited in Markham, The Letters of Amerigo Vespucci, pp. 63-65.

${ }^{59}$ Arciniegas, pp. 273-284.

${ }^{60}$ Roberto Almagia, L'Opera del Genio Italiano All'Estero, vol. I: Gll Italiant: I Primi Esploratori Dell'America [The Italians: The First Explorers of Americal (Rome: La Libreria Dello Stato, 1937), pp. 284-288.

61 Pohl, ch. 10.

62 Levillier, Américo Vespucio, pp. 29-30.

${ }^{63}$ Fragmentary letter (c. 1502) as cited in Arciniegas, p. 242.

64 Almagia, p. 378. 


\section{Chaptar IV}

\section{THE CABOTS}

Because of the mountain of literature which has been written about Columbus, it is eesy to forget that John Cabot set sall seaking the some gools only five years of ter Columbus' first voyege. The major difference is that Cabot selled under the British Crown. Little 18 known about Cabot becouse the leck of documentation concerning him or his son Sebestien. No written occount by this most fomous fother and son exploring team has surviyed, but from numerous contemporary sources it appears that such g document (or documents) once existed. From these contemporery, secondery occounts we con potch together the detalis of the Cabots' lives and discoverles. Their identity in the accounts is certain, even though their nemes appear in somewhat different forms as the various chroniclers struggled to spell nemes that were foraign to them.

John Cabot probably come under the influence of Columbus just as mony others of his time had. Records from Volenclo, Spoin of 1492 show that Venetion named Johan Caboto Montecolunya recelyed permission from the king to rebulld the port, but we are not sure if this wos the same men as the famous explorer. At any rate, the deal fell through, so we may never know.' If this man was the same John Cabot as the discoverer, he may have 
eesily conferred with Columbus before the latter's first voyege. The two men of like minds might also have met in Seville when Columbus returned from his second voyage in $1493^{2}$ is it not possible that Columbus might have shered the same ideas with Cabot that he had with Toscenelli, Vespucci, and many Europeen heads of state? ${ }^{3}$

We know that the Iberien Peninsule ot this time was yery open to Italians because of their contributions to geography, cortography, the arts, phllosophy, and of course, trade. It could be that John Cabot picked up on the ideos of Toscenelli and Morco Polo which were in wide circulation of the time. ${ }^{5}$ After all, Toscenelli's letter proposing a westword route to Asia Wos originally sent to the King of Portugal; Columbus merely heard it being discussed among sailors and cortogrophers and wrote to Toscanelli asking for a copy.

All of the explorers examined in this study spent some time in Spain and/or Portugal becouse they knew that was where oll of the lotest information on discovery was avatlable. Men in the Iberian peninsula openly discussed their notions of geogrephy snd proposels of exploretian, and competition for royal commissions was fierce. Most of the Italian discoverers formulated their ideas in Spain and Portugal even if they loter explored for other countries. Many of the Itelian explorers returned to these 
countries when potronege elsewhere folled or they needed a relieble income from teaching certography or naylgational techniques to others. John and Sebastian Cabot were no exception.

Numerous contemporary observers testify to the cortogrophicol and navigational ability of the Cabots. Polydore Virgil, the author of the Anglice Historia of 1512-1513 proclaims that John Cabot was "... Venetion by birth, and a most skillful meriner." $\mathrm{A}$ letter to the Duke of Milan at tributed to the ambassodor to England, Raimondo de Soncino, of August, 1497, stetes, "some months ago his Mojesty sent out o Venetien, who is a very good moriner, and has good skill in discovering new islands ... ${ }^{7}$ In another letter dated December 18, 1497, Soncino tells his sovereign, "there is in this Kingdom o men of the people, Messer Zoene Coboto by name, of kindly wit and a most expert mariner .... This Messer Zoene hes the description of the world in a mep, and also in a solid sphere, which he hos made, ond shows where he has been... He soys that on previous occosions he has been to Mecco, whither spices ore borne by corovans from distant countries." And finolly, The Greot Chronicle or Londion of September 1497-1498 describes John Cabot es "... venyzion which mede hym sylf verrey expert \& kunnyng In knowloge of the cyrcuyte of 
the world and 110 lendis of the seme, es by a ceart othir demonstracions Reosonable he shewid...."

Sebestian Cobot 18 described by Peter Mertyr d'Anghiere in his The Decades of the New World or West Indies of 1534 as " . . the very prudent and proctical noulgator Sebostien Cabot the Yenation, who when a child was token to Englend by his father, and on the latter's deoth, being very rich and of en enterprising mind, thought that, as Christopher Columbus had done, so he too wished to discover some new pert of the world. ${ }^{-10}$ Richerd willes in his work: The History of Trovayle in the West Indies and East Indies of 1577 tells us thot Sebestian Cobot " ... wos not only o skilful seo men, but - long trovailer ...."11 whose maps were better than those of Mercator because he had entered the northwest strait personally and that ${ }^{\circ} \ldots$ in his owne discourse of novigation you may reade in his corde drawen with his owne hends...12

Glovenni Bettista Romusio, on Italion historian and early collector of voyages of discovery, relates o story in his Primo Volume delle Navigationi et Vlaggi of 1550 told by Hieronimo fracastoro. Fracastoro was privileged to meet Sebastian Cabot ípossibly when Sebostian wes negotioting with Venice concerning o voyage of discovery which wos never carried out), view his globes and maps, ond discuss his plans for discovery. 
He recells that Sebestion was:

... 80 worthy and experienced in things pertoining to navigation and cosmography that in Spain there is not now his equal ... and for this reeson he is celled the Pilot Major.

... Unexpectedly I met this man and found him a most amiable and courteous person, who was very kind to me and showed me many things, and amongst others a large map of the world with the navigations set forth, both of the Portuguese and the Castllians. And he told me that, his father having left Venice many years ago and having gone to Englend to trade, he took him with him to the city of London, when he [Sebastien] was rather young, but not before he leornt the humenities and the sphere.

The remous British compller of accounts of discovery, Richerd Hokluyt, in his Divers Voyages of 1582 stated that the writings, maps, and globes of the Cebots were entrusted to one, Williem Worthington, untll such time that they be published " .. beceuse so worthie monumentes should not be buried in perpetuell oblivion.... ${ }^{14}$ Tregically, thot is precisely what heppened beceuse whether they were published or not, none of these works has survived.

Like Columbus and Vespuccl, John Cobot olso sought patronage Initially in Spain and Portugal. In 1490 the Spanish agent to the Crown in Englend sold of John Cabot, "I have seen the map made by the discoverer, who is onother Genoese like Columbus, who has been in Seville and at Lisbon seeking to obtain persons to oid him in this discovery. ${ }^{-15}$ Evidently Cebot 
was rejected, however, and had to look elsewhere. Just as in Columbus' case, the Portuguese turned down Cobot becouse they had reeson to believe thet their own esstern route to Asie would soon pay off. The Spanish turned down Cobot because they were still placing their hope in Columbus' Western route and in their own explorers. There were simply too meny imitators of Columbus in Spoin at the moment, and too few resources to spare for such endeovors ofter Spain's long wor ogoinst those that they colled the Inflidels. For the time being of least, the Crown defended Columbus' claim that the Indies had already been found and could still be persueded to supply ships to confirm the earlier findings. ${ }^{16}$

The English hod already been approeched by Columbus' brother Bertholomew in 1488, but hed turned him down. ${ }^{17}$ what interested them in Cabot's proposal was that he claimed he could reach Asie more quickly then the Spanish had simply by teking o more northerly route. Furthermore, he could ayoid the Spenish and Portuguese fleets and therefore any possible confrontetions with them. The English were still close enough to the Romen Catholic Church at thet time to want to avoid flagrent violations of the papal Treaty of Tordesillas, which had given the Spanish the Western Hemisphere to colonize and the Portuguese the East. At this stage England could III afford enother war after the tremendous drains of the Hundred 
Years' Wer with Frence and the War of the Roses at home. Only the promise of new weolth for Englend could cepture Henry VIl's interest. ${ }^{18}$

Fortunately, the logic behind Cabot's proposal wos very compelling. He ressoned that Asio would be closer to Europe from a northern opproech beceuse of the closeness of the bends of longitude os they begin to converge towards the pole. He sold that Columbus had not reached his gool merely becouse he had not gone ior enough west. Cabot cioimed that by seiiing west from England, the distence of the Atlantic pessege could be reduced. Then, by soiling southwest from the initiel lendfall, the inhabited parts of Asle could be reached before Columbus or eny Spenterd reeched them. The English would then be free to trode directly with the Asians and not haye to worry about Spanish or Portuguese interference. ${ }^{19}$

This wes a proposel besed on sound geogrophical reosoning by o man Who was well-yersed in the latest developments in cosmogrophy. Cabot's use of the globe to show the possibility of a shorter route to Asio was 8 more compelling visual aid then the one-dimensional sailing charts which most novigators used ot the time. A contemporary source tells us that Cebot's use of the globe is whet won the king over. Reimondo de Soncino related John Cobot's persuesiveness in the following: 
... He therefore reasons that these things [spices] come from pleces far awey from them Ithe Arabsl, and so on from one to the other, al woys ossuming that the earth is round, it follows as a matter of course thet the last of all must take them in the north towards the west. He tells all this in such a way, and makes everything so plain, that I also feel compelled to believe him. What is much more, his Majesty, who is wise and not prodigal, also gives him some credence. ... By means of this they hope to make London a more important mart for spices then Alexendrio. ${ }^{20}$

John Cabot was wrong in thinking that the source of spices was northern Asio, but right in essuming that they were tradisd from hond to hand many times from a source in the For East. What he could not have known, however, was that the figures which he was using from Ptolemy for the circumference of the eerth were too smell. Columbus had made the seme error, but by 1501 or so Vespucci had guessed os much beceuse of his own calculations. Therefore, although North Americe was proportionately closer in the high latitudes, Asia was still incredibly for awoy.

Like Columbus, Cabot probably died thinking he had found Asio. It is to his credit, however, that he did not further shorten Ptolemy's figures on the circumference of the eerth to menufacture plausibility for his arguments as Columbus hed. ${ }^{21}$ Hed Cobot llyed langer, he probebly would have seen the arror in his thinking and chenged his strategy as we know his son eventually did. In contrast, Columbus misled on entire generotion of Spenish rulers, explorers, and cortographers to believe he had found Asia. 
John Cabot had been very effective in convincing the English Crown to underwrite his enterprise, even though it was radicelly different from anything else the British had tried up to that time. Cabot's Ideas were well before their time for Englend of the 15th century. To the English, the North Atlentic was itttle more then a good fishery. ${ }^{22}$ The tales of Viking and Irish voyages of discovery and Nordic colonies in the islands of the North Atlentic were long forgotten. There were legends of such lends as the Seyen Cities of Cibole, the islands of St. Brenden, and Brasll, but until Cobot come along with o plen to reach Aslo by salling west there was little interest in voyoges of discovery. ${ }^{23}$

While living in Lisbon, Cabot heord many toles from the merchents from Bristol stationed there. They told him that in the early $1490^{\circ} \mathrm{s} \theta$ series of yoyages had gone out to the west from England, searching for new Pishing sites free from the control of Icelenders. ${ }^{24}$ Cabot heard of uncherted lands to the west of Iceland and thought thet they might be a port of Asie. It seemed to him that a voyege of discovery from those latitudes might be 8 worthwhile undertaking. Soon afterward he went to Bristol personally to investigate further and then he went to king Henry VII to try to convince him to sponsor en expedition. 
It is to Cabot's credit that he not only concelved the idee of o northern approech to reaching Asia, but was also oble to win Henry over. He produced an impressive collection of mops, globes, and documentery evidence to prove his point and soon had the king convinced. In typical Renaissence foshion, he combined knowledge from research with empirical eyeluation of new focts to beck up his theory. He also emphosized the practical benefits of exploration by convincing the king that he could have riches of Cipengu (Jepen), conquer the infidels, and claim new lands for England. The Letter of Patent issued to John Cebot on March 5, 1496 outhorizes him "... to find, discover and investigate whotsoever islonds, countries, regions or provinces of heathens and infidels, in whatsoever pert of the world pleced, which before this time were unknown to ell Christians." 25 He then agrees to give the bulk of the profits to John Cabot and his heirs, keeping only o fifth for himself. ${ }^{26}$

What more could Henry osk for? He enthusiostically bocked Cobot, and scored a bit of a diplomatic coup by manoging to sponsor the first voyage of discovery not conducted by members of the Treaty of Tordesilles. It was a coup because he did this without being drown into a conflict with Its signotories or his Continental allies. ${ }^{27}$ In fact, in future voyages the Portuguese cooperated with the English and managed to explore the 
Northwestern Atlentic without conflict beceuse they were hoping to exploit - loophole in the treaty by proving that the newly found territories were beyond the Line of Demercation showing those ereas belonging to Spein. ${ }^{28}$

They were unsuccessful in North Americe, but they did menege to demonstrate thet Brazil wos within their sphere of influence and thus they goined a toehold on o pert of the New World. For its pert, Spoin wos too preoccupied with developing its other possessions and defending its claim to the Philippines to get involved with defending its cleims to North Americe by force. The English steked o cloim in North Americe by virtue of the old axiom that possession is nine-tenths of the low and no one did onything to stop them.

Cobot set sell from Bristol obout the 20th of Mey, 1497, heading west to Dursey Head, Ireland, and from there westward in olmost o direct line to Newfoundiand. Ironically, his landing was within a few miles of Lelf Ericson's nearly five hundred years before, but any trace of the colony that Ericson had left was gone, and the voyage itself long forgotten. ${ }^{29}$ cabot cloimad the land for Englend, but olso planted the banner of St. Mark as o tribute to his native venice. He did not spend much time ashore, but he did have time to observe the inhabitents, as $\%$ shell se日 shortly. He explored the waters near Newfoundland, searching for a strait that would open up to 
Asie. When he thought thet the had found it, he returned to Englend to plan a larger expedition which would investigate further. He could not take chences at more entensive suploration becouse he was short of supplies and had just one ship, the Mattee or Matthew, with only o small crew.

Cabot wos unable to prove that the lend he had found was Asio, but he did furnish evidence that it wos inhobited, hoving found poths, compfire sightings, game snares, a needle for making nets, and other man-made objects. He also saw felled trees, cultured fields, and animal droppings, which he interpreted as signs of agriculture. This creoted enough excitement in England to cause most people to believe that Cabot had done What he had set out to do. Lorenzo Pasqualigo, a contemporory of Cabot. wrote to his brothers in Venice on August 23,1497: "He has discovered mainland 700 leagues awoy, which is the country of the Great Khen ....30 Similerly, Soncino wrote in the same year to the Duke of Milen that Cabot had discovered the Seven Cities of Cibola and "... gained a part of Aslo without a stroke of the sward. ${ }^{31}$ Finally, John Doy in an undated letter to the "Lord Grand Admiral" of Spain (probably Columbus) reported that John Cabot had confirmed the findings of the Bristol merchents who had earlier cleimed to have found the Isle of Brosil. 32 John Cabot was warmly received in Englend upon his return. Pasqualigo said that " . . he is 
colled the Great Admiral and a vast honor is poid to him and he goes dressed in silk, and these English run af ter him like mad ....33 This lovish spending on the pert of Cabot was made possible becouse the king gave him a government stipend for life and granted a charter for a secend yoyege. ${ }^{34}$

Soncino relates that Cobot told him that:

The land is excellent and temperate, and they belleve that Brazil wood and silk ore notive there. They assert that the sea there is sworming with fish, which can be taken not only with the net, but in baskets let down with o stone, so that it sinks in the water. I have heerd this Messer Zoone state so much. These some English, his compenions, sey that they could bring so many fish that this kingdom would heve no further need of Iceland .... But Messer Zoone has his mind set upon even greoter things, becouse he proposes to keep along the coost from the place ot which he touched, more and more to the eost, until he reoches on islend he calls Cipango, situated in the equinoctiol region, where he believes that all the spices of the world have their origin, os well as the jewels. ${ }^{35}$

As fate would have it, however, tragedy would rain on John Cabot's life es it did on so many other explorers. Something went wrong on his second voyage, the nature of which remains uncertain, beceuse of scenty ovidence. He was elther lost of sea, or he returned to Englend o foilure ond retired in ignominy. As Polydore Virgll, the writer of the Anglica Historia rather unceremoniously put it: "In the event he is believed to have found the new lends nowhere but on the yery bottom of the oceen, to which he is thought to have descended together with his boat, the victim himself of that 
self-same ocean; since of ter that voyage he was never seen agoin onywhere. ${ }^{36}$ Either way we know that it soon became known in England from those who did return thot he had not found what he had sought. 37

The detalls of what John Cabot found on his second voyege are sketchy, but the few facts that we do hove are enticing. Pedro de Ayalo sent an alermed letter in cipher to the Spenish soyereigns on July 25, 1498, that the British were beginning to encroach upon lands claimed by Spoin. He cried, "I find that what they have discovered or are in search of is possessed by Your Highnesses by the convention with Portugel [The Treety of Tordesillosl. ${ }^{36}$ He further claimed that Cabot faked his maps to make it oppeer thet the lands discovered were not part of those cleimed by Spoin. ${ }^{39}$

The Spanish historian, Alonso de Santa Cruz, tells us in his Islario General de Todes les Islos del Mundo, written in 1541, that:

... [John Cabot] had coasted the land and northern shore even forther then the land of the Bocolleos [Newfoundiand] and almost os for os Floride, that even in July there were such great floes and messes of ice on the see, lerger than their ships, which ceme olong the coest propelled by the currents, that they could herdly keep clear of them. 40

He then credited Cobot with discovering Labrodor and some smaller islands and stated that by the time of his writing the English frequented the areo, extrocting lorge quantities of fish and voluable trade in furs with the 
lerge netive population. He further reesoned that the areo which Cabot found was a mainland by virtue of the large rivers located there. 41

A map which was supposed to have been created by Sebostian Cabot $^{42}$ has o norrotive which combines eiements of John Cobot's iirst and second yoyeges in o lagend corresponding to the areas he discovered. It describes the natives as follows:

The people of tt are dressed in the skins of animals; they use in their wars bows and arrows, lances and derts, and certain clubs of wood, ond slings. It is a yery sterile land. There are in it many white bears, and very large stags like horses, and meny other animals; and likewise there is infinite fish... and likewise there ore in the seme land hawks like block crows, eagles, pertridges, linnets, and many other birds of different kinds. ${ }^{43}$

Finally, o clue os to whot might have been the fate of John Cobot is found in a letter of Pietro Pasqualigo to his brothers in Venice, dated October 19, 1501. He related the expedition led by Gespar Corte Real to foliow up on Portuguese claims to the areo (hoping that it was east of the Line of Demercation of the Treaty of Tordesillos) and soid that they found among natives knowing of no metels "... a plece of broken gilt sword, which certainly seems to have been made in Itoly. One of the boys was wearing in his ears two sllver rings which without doubt seem to have been made in Venice. ${ }^{44}$ Historians differ as to whether this indicated the signs 
of o bettle that wos fought end lost, Items ebandoned by the Cobot expedition in heste, trede items, or nothing ot all. ${ }^{45}$

We know slightly more obout the life of Sebestian Cabot beceuse he died at a very oid age of neturai couses and hed gathered e great many friends and much influence during his long career. We even heve s unique example of a map which bears his name, though his role in its construction is disputed. We do not have a surviving written account by him, however, 80 as with his father, we must potch together the details of his yoygges from his contemporaries.

Sebastian's most important contribution was turning the tragedy of his father's death into victory. He wos instrumental in developing England's exploration policy to the west and to the eest by continuing the search for pessages to Aslo. Hoving probably accompenied his fother on his yoyages, he set out on a yoyege of his own 1508 to canfirm his father's findings. When it became clear to him thot o strait opening up to Asio was not where he had expected to find it, he sought the Northwest Pessege to bypess the "Firstseenland" end go to Asle directly instead. Sebestian did not accept defeat or stubbornly defend the impossible; insteed he opened a whole new epoch in the Age of Discovery by Initiating a search by the British and French for this passage which would last for nearly three-hundred years. 
During the course of his cereer Sebestien would chenge his direction of exploretion many times as he received updated information regerding other discoveries.

Peter Martyr of Anghiera in his De Orbe Novo Decedes of 1516 discussed the various water routes which were being explored as possible openings to Asio. He noted that all the currents flowed westword in the lands found thus for, and thereby reasoned (incorrectly) that there must hove been on opening towards which oll of these waters flowed, thus allowing pessege to the seas of Asio. He then discussed the frozen waters of the north explored by Sebestion,

He equipped two ships at his own cost in Britoin, and with three hundred men steered first for the north, until even in the month of July he found great icebergs flooting in the seo and olmost continuous daylight, yet with the land free by the melting of the ice. Wherefore he was obliged, as he says, to turn and make for the west. And he extended his course furthermore to the southword owing to the curve of the coestline, so that his latitude was almost that of the straits of Gibraltar and he penetrated so far to the west that he had the islend of Cubo on his left.... 46

Following that, he described the land that Sebostion found:

Cobot himself colled those lands the Baccolloos becouse in the odjocent seo he found so great o quantity of o certoin kind of great fish like tunnies, called bocolloos by the inhobitants, that ot times they stoyed the possage of his ships. He also found the men of those lands clothed in skins and not anywhere devold of intelligence. He says there ore great numbers of beors there, which eat fish... on 
which account, he says, the bears ore less dengerous to men. Many say that they have seen copper ore in places in the hands of the inhabitants.

I know Cabot as a fomiliar friend and sometimes as o guest in my house.... 47

Ramusio recorded in 1550 that Sebastian also confided the above to

Hieronimo Fracastoro, recalling that upon hearing of Columbus' discoyeries:

There was born in me o greot desire and on eagerness thet I should do some signal deed also, ond knowing by reason of the sphere that if I sailed by way of the north west I should have a shorter rood to find the Indies, 1 at ance communicated my thought to his mojesty, who was very pleased and equipped for me two corovels with oll things needful .... And I began to seil towards the north-west, thinking not to find land until I come to Cothoy, and from thence to turn towards the Indles. But ot the end of some days I discovered lond, which ran to the north, which greotly displessed me... 48

He continued southword elong the coest:

...always with the purpose of finding a passage to the Indles, and come os for os that pert now celled Florido. And, my victuals being short, I decided to return to Englend, where, on my arrival, I found great disturbances, of the people in rebellion and of o wor with scotlend. There was no further thought of sailing to those perts, for which reason I ceme to Spoin. ${ }^{49}$

Once in Spein, Sebestion put his telents to good use. The king oppointed him to take up Vespucci's old job as Pilot riajor for the Spenish nevigators. While in this office he wos octive in certogrephy, exemining pilots, outfitting voyoges, and serving as an expert witness in negotiations arising from territoriol disputes between Spain and Portugel oyer the lands 
recently discovered. ${ }^{50}$ For a brief perlod from 1522-1523 Sebastian secretly negotiated with Venice to conduct a new expedition to explore the Northwest Pessege. The Venetians appealed to Cabot's loyalty to his country of origin, but neither perty could surmount the difficulty of conducting a secret yoyege under the noses of the Spanish and Portuguese without being detected. In the end, Sebostion stayed loyel to Spain and the expedition never took plece. 51 This was as close as an Italian state would eyer get to conducting an original voyage of discovery of its awn, though routine commerciol yentures to the New World would become common.

He also led an expedition to search for a passege to Asta through the Rio de lo Ploto in South Americo. This 111-fated yoyage began on April 2, 1526. This expedition was originaliy commissioned as a follow-up to the success of Magellan's crew in finally reoching the spice islonds by sailing west, but at some point Sebestian decided to chenge the objective of the voyage. The reasons for this were unclear. ${ }^{52}$ The expedition wos divided in its purposes from the beginning because its priyate backers were in search of a quick profit and the king only wanted to obtain geopollticel informetion Which might be useful to him later. This brought about strife and division among the officers representing both sides which was no doubt exacerbated by those who resented having a foreigner in command. The dissension among 
the officers and crew resulted in severel mutiny attempts and the loss of the flogship on the rocks during a moment when command broke down.

Soon after this, Sebostian found survivors of the de Solis expedition which he rescued north of and around the Rio de la Plate. They told him teles of limitless silver io be found inlend. He proceeded to explore the mouth of the river and the Parano and Uruguay rivers that feed into it to follow up on claims by the natives of huge omounts of sllver and a large oceen to be found to the west of the mountoins. After yeors of plodding through the jungle and exheusting themselves exploring treecherous and hostlle upriver arees in smell boets, Sebastian returned to Spain in July of 1530 with only one in ten of his original crew because of starvotion, disease, and Indian attecks. He brought back with him only some gold and silver artifacts and sloves to show for his efforts. The king wos grateful for the geographical and strategic information gothered, however, and the promise of riches would couse numerous Spenish expeditions to suffer hardships in the oree untll the native population was subdued and the oreo developed. 53

Upon his return to Spain, Sebastian was taken to court by his enemies over alleged misconduct and abuse of command (much like Columbus) and was fined ond sentenced to exile. The king overturned this 
sentence, howeyer, and reappointed him to the post of Pilot Major. ${ }^{54}$

During his remaining time in Spain he worked on a theory for determining longltude with the use of magnetic variations and another by using the sun's declination at midday and comporing it to the recorded level at a known locetion. Weither of these produced immediate, reliable results, but they show an active mind engeged in practical, scientific endeavor, nonetheless. 55

After the mixed results of this mission, and with his popuierity probably folling, Sebestien begen to consider looking for sponsorship elsewhere then Spain once again. When his Spenish wlife, Doñe Cateline, died in 1547, his last tie to Spoin was gone. He returned to Englend and beceme quite busy 08 a certographer and sponsor of yoyeges. Finally, when he was quite old he was instrumentel in beginning the search for o Northeest Pessege. He was the Governor of The Merchent Adventurers of Englend for the Discovery of Lends, Territories, Isles, Dominions and Selgnorles Unknown" which later became known as the Muscovy Company. He sponsored and outfitted expeditions, but he did not cerry out them out himself. He was finally able to realize the lifotime dream that he and his fother had to bring Asion trade to England, becouse the Muscovy Company ultimately broke the trade monopoly of the Hanseatic Leogue by travelling 
to Moscow end arrenging a trading treaty in 1554. After a long life, full of accomplishments, Sebustian died in 1557 at the odvanced age of seventy-three. 56

Unfortunately, in their haste to forget John Cobot's follure to find Asio, the British dropped his name entirely from their chronicles, ond his yoyoges were populerly associeted with those of his son even while Sebastlan was still alive. John was forgotten by his contemporories beceuse he had falled; his son lionized because the prospect of a Northwest Possage still held some hope. ${ }^{57}$ If history wos truly rewritten in this way, It would be a fascinating example of the selective memory of popular history, which has so distorted our image of many of the explorers. Often we remember things the way we want to see them.

As a result of the fallure of the Cabots to find a shorter west ward route to Asio, the British switched their explorotion policy. They bypassed the newly-found lands and continued on in search of o Northwest Passage. An important consequence of this wos that even though they had reached the North Americen Mainland olmost os early as the Spenish explorers had, they postponed its development and exploitation until oround 1600 .

The chaice of the British to postpone the colonization of the lands found by the Cabots can be explained by a number of factors. The most 
Immediate of these was that when Henry VII died his successors were not as interested in spansoring exploration as he had been, and there was a temporary lull in British discovery ofter the voyages of the Cabots. This is why Sebestien moved to Portugal and then Spain; he could no longer find sponsorship in Englond. 58

Secondly, the British had not recelyed returns on the yoyages which had been sponsorad to date. Interest in voyages of discoyery was ot iost renewed in Francis Droke's time, but only becouse the British privateers could alwoys foll back on plundering Spanish galleons looded with gold from the New World to meet expenses if their yoyages of discovery were not profitable. British voyages of this period usually only retraced the steps of others or wosted time on dead-end ottempts ot Northwest or Northeest Passeges. Only of ter the defeat of the Spenish Armode did the British feel comfortable with sending lerge numbers of settlers to North America becouse they knew thot the Sponish were finolly powerless to stop them. ${ }^{59}$ As we have seen, the Cebots were instrumentel in searching for alternste routes to Asio then those sought for by the Spanish and the Portuguese. This helped to leed to the beginning of the British ero of discovery and the ultimete British settlement of North Americo. By-products of their efforts were also the opening up of English trode with 
Muscovy and the further exploitation of the interior of South Americe by the Spenish. Their discoveries forced the Spenish and Portuguese to hammer out some of the finer territorial disputes resulting from the Treaty of Tordesillas. Accordingly Spain and Portugal began to send new explorers inland to try and solidify their claims and develop the interior of the new continents.

The Cabots used the same methods as other Humanist cortogrophers in the preperation for their yoyeges, and Sebastian Cabot ot least would be able to revise his cosmography as new experience dictated in much the same way as Vespucci did. We know that their discoveries and cartography had o profound effect on the theoretical conceptualization of the New World ${ }^{60}$ and inspired many others to investigate it further. It is a pity that none of their own writings or mops haye survived or we might know more of how their thinking was influenced by humanism. StIII, we have seen that in the opinion of many of their contemporaries they were men of learning and expert moriners. 


\section{Notes}

'As cited in James A. Williemson, R. A. Skelton cartographer, The Cobot Voyoges and Bristol Discovery under Henry VII, Glasgow: Robert Mac Lehose \& Co. Ltd. published for the Hekluyt Society, Cembridge: Cembridge University Press, 1962, pp. 196-199. It is unclear whet the neme Montecalunye meant as it appears nowhere alse.

${ }^{2}$ Ibid., pp. 40-42.

3 ibid., pp. 55-56.

${ }^{4}$ Frederick J. Pohl, Amerigo Vespucct: Pllot Mojor (New York: Morningside Heights: Columbia Univarstitu Press, 1944), p. 34.

5 Ibid., p. 8.

6 As cited in Williamson, p. 225.

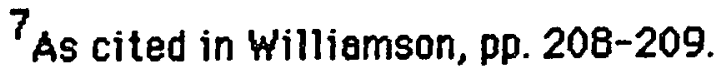

${ }^{8}$ As cited in williamson, pp. 209-210.

${ }^{9}$ As cited in Williemson, p. 220.

10 As cited in Williamson, p. 268.

11 As cited in Williamson, p. 279.

12 ibid.

13 As cited in williemson, pp. 271-272.

14 As cited in Williomson, p. 280.

15 As cited in Williemson, p. 228.

16 williamson, p. 42.

17 The story of this trip is recounted for us by Christopher Columbus' son Ferdinend in Le Historie di Cristoforo Colombo as cited in Williamson, pp. 199-200.

${ }^{18}$ Charles E. Nowell, The Great Discoveries and the First Colonial Empires, (London: Cornell University Press), 1974, p. 113.

19 williamson, pp. 45-53. 
${ }^{20}$ Soncino letter of December 18,1497 , As cited in Williamsan, p. 210.

21 williamson, p. 16.

22 Ibid., p. 3.

23 Ibid., pp. 3-18.

24 Ib1d., p. 43.

25 As cited in Williamson, pp. 204-205.

26 Ibid.

27 w!ltiameon, pp. 5 !-52.

28 Ibid., pp. 116-144 in passim.

29 According to Samuel Morison's calculations in The European Discovery of America: The Northem Voyeges A. D. 500-1600, (New York: Oxford University Press, 1971), ch. 6.

30 As cited in Williemson, p. 206.

31 Soncino letters of August 24th and December 18th of 1497, as cited in Williamson, pp. 208-209.

32 williamson, p. 213, also pp. 87-88.

33 As cited in Williamson, p. 208.

34 Williamson, pp. 84-94.

${ }^{35}$ As cited in Williemson, p. 210.

36 As cited in Williamson, pp. 224-225.

37 williamson, p. 105.

38 As cited in Williamsan, pp. 228-229.

39 Ibid.

40 As cited in Williamsan, p. 231.

$41_{\text {Ibid., p. } 232 .}$

42 Although Williamson disputes its authenticity due to errors in detes, lenguage, and inaccuracy in the areas Cabot knew. He does confide 
that Sebostion may have lent his nome to the project, but did not inspect the finol product. Williamson, pp. 57-59. Roberto Almagia in L'opera del Genio Italiono All'Estero, vol. 1: Gli Itoliani: I Primi Esploratori Dell'Americe (The Italians: The First Explorers of Americal (Rome: Lo Librerio Dello Stoto, 1937), suggests that the unclear areas were deliberately kept vogue by Sebastion to protect stote secrets.

${ }^{43}$ As cited in williamson, p. 207.

44 As cited in williamson, p. 230.

${ }^{45}$ See Morisan, Northerm Voyages, p. 180 and Williamson,

pp. 106-107.

46 AS citeú in Hîlitomson, pip. 266-26?.

47 Ibld., p. 267.

48 As cited in williamson, p. 272. Note that some of the dates and details of this account are confused with those of John Cabot as the story was being told third-handedly.

49 Ibid.

${ }^{50}$ Almogio, pp. 316-317. Interestingly, Ferdinand Columbus and Giovanni Vespucci were olso involyed in the negotiations.

51 See Williamson, pp. 282- 285; also Almagio, pp. 314-316.

52 Almagia claims Cabot changed objectives becouse he had lost his fleg ship and the remaining crew and ships were in no condition to go as far os Asie (p. 317). Williamson, in the final chapter of his earlier work entitled The Voyeges of the Cabots and the Discovery of North America, (London: Argoneut Press, 1929), proposes that o secret poct existed between the king and Cabot to go to Rio de lo Plate instead of Asio and that Sebastien was just following orders occordingly. Characteristically, Morison in Ch. 22 of The European Discovery of America: The Southern Voyages: 1492-1616, (New York: Oxford University Press, 1974), ciaims that Sebestion was an incompetent froud who had invented his earlier yoyage to the Northwest and was unit as a commander in this ona. He says that Cabot made serious errors in navigation, cartography, and command, and his only motive for exploring the Rio de lo Plate was greed for goid and sllyer. The question remoins how such an incompetent could conduct so 
meny yoyages of discovery in yastly different climates ond hold responsible and trustworthy commands over the lives of other novigators in both Spain and England!

${ }^{53}$ The foirest and most unbiesed eccount of this yoyege can be found in The Voyages of the Cabots and the Discovery of North Americe. Although the outhor admits that it is a cursory treatment, no one else has covered the subject in greater detail since. Almegio's treatment of Sebestian Cabot is thorough but a little too apologetic and Morison ignoras a great deel of positive character description from other sources which for outweigh this one example of bod judgement and possible cheracter flaws in the area of command. As with many other explorers Sebastian Cabot has been neediessiy maiigned due to incomplete information used by scholars.

54 The testimony of Cabot's enemies in this trial was the source of most of the defamation of Sebestian's cherecter. Much the same thing happened to Columbus possibly because of nationalistic suspicion and resentment of foreign commenders by native Spaniards. Morison makes the some mistake as many 19th Century historians by placing too much woight on these sources in an at tempt to essessinate the charecter of Sebestion.

A more balanced assessment such os Williamson's shows that most of Cabot's contemporaries liked and trusted the man, and that his foilures were no worse than many other conquistadors.

55 williamson, The Voyeges of the Cabots and the Discovery of North America, pp. 279-280.

56 Ibid., pp. 281-284.

57 williamson, The Cabot Voyoges and Bristol Discovery under Henry VII, pp. 95-97.

58 Ibld., pp. 170-171.

59 James Edward Gillespie, A History of Geographical Discavery: 1400-1800 (New York: Henry Holt and Company, 1933), p. 66.

${ }^{60}$ R.A. Skelton discusses the influence of the Cobots discoveries on cortogrophy in the final chopter of The Cabot Voyoges and Bristol Discovery under Henry VII. 


\section{Chopter $Y$}

\section{GIOVANAI DA VERRAZZANO}

Sebestien Cebot's finel yoyages revolved around trying to find alternative routes to Magellan's passege to Asie, 'but he was not the first Itolien explorer influenced by Megellan. Giovannt do Verrazzeno, o young Florentine merchant, was briafly acquainted with Magellan whlle they ware in Spain and Portugal. Antonto de Sllyeira de Meneses, the governor of Mozambique, Hrote a latter in July of 1518 to the King of Portugel stating that Verrazzano had bean in Lisbon and had accompeniad Magellan when Magellan left Portugal to offer his services to the King of Spain. We cen only speculate as to what idees of discovery the two men might heve discussed or to why Verrazzano decided not to go with Magellan on his attempt to circumnovigate the globe in the Southern Hemisphere. Pertiops Verrazzano had already thought to try a shorter route in the Northem Hemisphere. Unfortunately, the documents tell us nothing further of their relotionship, but Verrazzeno must have heerd of the return to Spain of Magellan's ships after thair leader's untimely daoth in tha South Paclfic, ond he must hove been influenced by the news that Asio could be reeched by solling west. 2 
By the time that Magellen's crew returned to Spain in 1522, the only mejor nation in Europe which did not have a stake in the discovery of the New World wos Frence. Frence wes going through o difficult time in its history becouse it found that its troditionel power which come from being one of the oldest and lergest monerchies in Europe wos suddenly and seriously riveled by the upstert Spain. Spein had used the wealth of its New World colonles end Europeen dependencles os well es the momentum of its unificotion movemeñit to amass a poweriul millitary end allience system. France was now surrounded by a hostile Spain which also controlled the Holy Romen Empire and the Low Countries. France's attempts ot militery intervention in Itoly were being thworted by Spoin ond the Holy Romon Empire, and Fronce begen to look elsewhere for a place to exercise its power. For these reesons the Now World begen to look appealing. Once France overceme the difficulties of its internel religlous wars stemming from the Protestent Reformation, it was willing to look for oyersees possessions, but by that point oll of the best sites were olready token by the other Europeen powers. 3

France also become interested in seeking trade with the East because it faced a degree of economic isolation due to its largely Medieval economy. France was dependent on Italian merchents for credit and 
Industriel goods because its aconomy wes entirely domestic-oriented and had no means of distribution for imported luxury goods, nor could the Crown roise enough money through taxes alone to pinence its meny wars. The French were tired of peying for goods second-handedly of exorbltant prices, ${ }^{4}$ and wished to find an unobstructed route to Asio of their own. Furthermore, Frence was somewhot jealous of the other powers' colonies and was encouraged by England's success in challenging the monopoly of Spain and Portugal in the New World. Slowly Franca bagan to bulld an interest in the New World as a way to gain wealth on independence for itself.

So it wos that Francis I was ready to listen when Giovanni do Verrozzano appealed to him for support for an expedition to explore o yet-untried route to the East. Froncis I was very open to latest Italian Ideas and influences and occordingly surrounded himself at court with meny Italian artists, chefs, generals, ministers, mistresses, and bonkers. Verrozzeno wos well at home ot the court of Frencis I beceuse of his widespread poironage and acceptence of lteliens. Verrazzeno's longtime residence in Frence and influentiol French friends were slso helpful in getting him an oudience with the King. 5 
We know little of Verrezzano's early days except to sey that he was o Florentine by netionolity, but lived and worked in o foreign country. This wos in keeping with the trodition of many other florentines before him, but it is unknown whether he was actually born in Florence or not. Regardless of his birthplece he was still considered a Florentine by his contemporeries, ond his essociotion with the Fiorentine colony of merchents and benkers living in Lyons proved to be of great benefit to his coreer as an explorer. ${ }^{6}$ He wos related to the Ruccellai famlly, banking partners of the Medicl and the benkers of Jean Ango, onoted Humenist and outfitter of vayages of discovery. He knew Zanobio Rucellal well enough to place him olongside his own brother Girolomo in the handling of his estate. ${ }^{7}$ He wos olso related to the Guadagni fomily, a wealthy group of Florentine exiles who helped him. Other supporters were the wealthy Albizi, Buonoeccorsi (spelled Boncorsy by the French), and Gondl familles. In fact, the list of his financial beckers reads like olist of "Who's Who" among Florentine bankers abroed and included representetives of some of the most wealthy and Influential families in Florence. Verrozzano would ultimately underteka his voyage of discovery with the backing of the king and his friends and in $\theta$ kind of joint venture between royel and private capital. ${ }^{8}$ 
While besed in Lyons he obteined experience as a nayigator and troyelled widely in the Levent while in the employ of Florentine and French merchants. Bernerdo Carli, a Florentine merchent, wrote to his fother in Florence in 1524 that Verrazzono had lived in Cairo for a period of several years, "... and not only in Egypt and Syrie, but also oll the known world, ond thence by reeson of his merit is esteemed enother Amerigo Vespucci, enother Ferdinand Magellan and even more. ${ }^{-9}$ Everywhere he went he axchanged news about recent discoveries and added to his geographical knowledge. He and his brother Girolemo began making maps and globes, described as "excellent" by Richerd Hekluyt in his Divers Voyeges of 1582 and 1584 , so much so that they were given to the royal family. ${ }^{10}$ Unfortunately, the only one which hes survived is Girolamo's world map. Among the finest of its time, it olso included the voyages he undertook with his brother, and many later maps were besed on it."

During his travels and geogrophical studies Verrazzono began to formulate in his mind the 1 dee of exploring North Americe for o passege to Asio. He moy hove olso taken part in the Aubert expedition, which explored in the aree of Newfoundlend in 1508, though the evidence is sketchy. ${ }^{12}$ In any cese, he had no trouble identifying Newfoundlend when he later explored the eestern coostline of North Americe. 
Whether he hed been there before or not, it was known since the time of John Cabot thet the only remaining possibllity for an undiscovered Northern Possoge to Asio loy in the hope of a stroit opening up somewhere olong the eastern coest of North America. ${ }^{13}$ In foct, only the Atlantic seaboard south of the British claims in Newfoundlend end north of the Spenish claims in Floride remoinad open to explaration, so Verrazzano led on expedition in 1523 to survey this coestline for o possege to Asio. He carefully ovoided encroeching upon the claims of others and embroiling France in a diplometic bettle with its neighbors. As it was, news of his plans leaked out before he ever set soil, and the olarmed Portuguese, who had been exploring in the area, sent envoys to Frence to discuss potentially rival claims. The primary result of this was that Verrozzano's fleet was reduced from four ships to one in the hopes of avoiding detection. 14

Verrazzeno did not find the passage to Asio that he sought, but he did provide Europe with a valuable geographical, notural, and ethnographical report of this last unknown stratch of the westarn shores of the Atlontic. His descriptions of the lands he found and the people he met are emong the finest of any explorer before or since. It has been suggested that Verrezzono's writings show the earmarks of a humanist education becouse of the quality of the language he used, the literary ollusions, and his 
knowledge of mothematics and science. ${ }^{15}$ In his letter to the King of France upon his retum he included meny clessicel allusions. For exempls, Verrozzeno described a perticuler forest he hed seen as Hyrcenion, called enother beautiful spot Arcedie, compered an islend to Rhodes, and soid the native women of one locele wore their hair like those of Egypt and Syrie. ${ }^{16}$

In the spirit of the new certogrophy of the Renolssence, Verrazzono recognized the difference between whot the Anclents knew ond what wos naw knowladge. Ha wostad no time declaring in the very beginning of his letter to king Frencis I that, " ... there appeared a new land which had never been seen before by any men, elther ancient or modern. ${ }^{17}$ Awed by its beouty he wrote obout a plece where, "... we could see o stretch of country much higher then the sendy shore, with meny beoutiful flelds and plains full of great forests, some sperse and some dense; and the trees hove so many colors, and are so beautiful and delightful that they defy description. ${ }^{-18}$

Verrazzono said that the Native Americans "resemble Orientals, perticulariy those from the forthest Sinarian regions, ${ }^{19}$ which means inat he either guessed at the Notive Americons' Asion ancestry or merely sow What he wanted to see, thinking that he wos in Asio. Unilike other explorers who lumped all natives together as a race of seyages, it is to Verrazzano's 
credit that he corefully recorded differences in eppeerence, dress, customs, and culture among the different groups that he encounterad. Overall, his tone when describing the natives wes not ethnocentric, condescending or judgementel. 20

Much like Marco Polo in his accounts of Aslo, Verrazzano wos cereful to point out potential trode commodities and mineral sources he encountered. He described the land not only in terms of its beouty, but in terms of its potential for harboring ships, cuitivating crops, and landing troops. Like all of the other ltelien merchent discoverers, Verrezzeno did not neglect the commerciol aspects of the yoyage nor the natives' receptivity to conversion, beceuse he knew the importance of renewed potronege ot home.

Verrezzeno very succinctly stated the purpose of his voyage of discovery and then candidly reveeled how his notion of cosmology was changed by it. He states,

My intention on this voyege was to reach Cathay and the extreme eestern coest of Asio, but I did not expect to find such an obstacle of new land as I have found; and if for some reason I did expect to find it, I estimeted there would be some strait to get through to the Eastern Oceen. This wos the opinion of all the Ancients, who certainly believed that our Western Ocean wos joined to the Eastern Oceen of India without any land in between. Aristotle supports this theory by arguments of yorious anaiogies, but this opinion is quite contrary to that of the moderns, and has been proven folse by 
experience. Nevertheless, lend has been found by modern men which appears to be larger then our Europe, then Africo, and almost larger than Aslo, if wo estimate its size correctly. ${ }^{21}$

What more concise end precise stetement of the beginning of modern thinking could there be? Clearly Verrazzeno had no trouble distinguishing his age from those pest or in redefining his world yiow as new information required it. With Verrozzeno's clear admissions we have left behind the shedows of doubt that piegued Coiumbus. The new generation of explorers thet followed Verrozzeno could freely discerd their outdated notions of cosmology and redrow the mop as they went along.

Verrozzeno's observations provided those who followed him with o great deal of valueble information. He in fact complled a "littie book" of longltudinal, tidol, and ostronomical observations which he soid "... would prove rather useful to nevigators. ${ }^{22} \mathrm{He}$ told the King that ha hoped that the book would thereby promote science. ${ }^{23}$ Tregicelly, this book, like so many others by the discoverers, is lost. Nor do we have written accounts of any of his other yoyages. They would have no doubt shed more light on Verrozzono's intriguing life and accomplishments.

Verrezzeno contributed much to our knowledge of navigation and of North Americen native populetions, flore and faune. In o major error, howeyer, he felt that the amount of land that he discovered in the New 
World proved that there was more land on earth than water. Another error wes thet he mistook the sendbars off the eestern tidelends of North Americo os an isthmus with o greot oceen lying just beyond. He did this becouse of his zeal to find a strait which would provide a potential opening to Asio. These errors confused mapmakers for sometime afterwards becouse they drew an otherwise correct North Americen coestline with the addition of an inlend see neerly touching the lands that Verrozzano described or continued to draw North Amerlce as a huge extension of Asio. ${ }^{24}$ This is despite the fact that Verrazzono soid, "all this land or New World which we have described above is joined together, but it is not linked with Asia or Africo .... Therefore the continent would lie between two sees, to the eest and west; but these two sees do not in fect surround either of the two continents. ${ }^{25}$ Verrazzano must have realized his error, however, beceuse he never returned to try to substentiete his cleims. Insteed he turned to commercial ventures along known coosts and attempts to find a previously overlooked pessageway to Asia in Central or South Americe.

Perhaps Verrazzano knew of Sebostian Cabot's attempts to follow up on the Magellan expedition, and planned to do the same. Verrazzano led on expedition to explore the Southern possege in 1526, but it fell into disarray when his ships were unable to pess through the Stralt of Magellan 
because of severe weather conditions. Unsure of their chences for survival In the rough seas, they decided to turn east and try to round the Cape of Good Hope in Africe end go on to the Indien Oceen insteed. It was known that the Molucces could be reeched by thet route, and trode there would make the commercial backers of the yoyege happy. Unfortunately, only one ship succeeded in rounding the Cape of Good Hope, and continuing on to the Molucces. That ship ended up shipwrecked in Madagascar however, and was never heard from again. Meanwhile, having lost contoct with this coptoin, Verrazzeno and his brother Girolemo gave up hope for him and decided to turn west and return to Brezil. The Verrazzeno brothers took on brazllwood on the return trip to solyege the expedition commercially, but little was accomplished in terms of discovery. ${ }^{26}$

Equally uncertain is the nature of Verrazzeno's death, but it is now generally accepted that he met on untimely death along with his crew in 1528 ot the hands of connibals (possibly Ceribs) somewhere in the Coribbeen while en route to seerch for a pessege through Central Americe. Some historisns heve confussd him for s pirsto nemed Jeen florin who wes executed by the Spenish in Noyember, 1527. Archival documents of the Parliament of Normandy prove, however, that in April of 1528 he was still alive and negatiating the payment for a craw and ship to conduct a final 
voyage of exploration to Americe. ${ }^{27}$ Neither Verrezzeno nor his crew were to survive the trip or find the passege, but an investor in the voyege paid to return the ship and its valuable cargo of brazil wood to its home port of Fécamp and recoup the investors losses ond os best he could. ${ }^{28}$

Two reliable pieces of testimony racord how his death octually took plece. One is the Storio Poetice by Glulio Giovio of 1560 which reeds, They were token by cruel people who suddenly ottocked them. They were killed, leid on the ground, cut into pieces end eaten down to the smollest bone by those people. And there also wes Verrozzano's brother who sow the ground red with his brother's blood, but could give no help, being aboord the ship. He saw everything and, hoving later come to Rome, one day he told us, in teers, obout this bitter event. Such a sed death had the seeker of new lands. ${ }^{29}$

Another piece of testimony is provided by the greet historien of nevigation and discovery, Glovenni Bettiste Remusio, in the third volume of his Novigationt et Vtaggi of 1556. He 8ays that Verrazzono's letters of other voyages were "... lost in the trovails of the poor city of Florence, ${ }^{, 30}$ and thet Verrozzeno and his landing perty were

... roested and eaten, such on unheppy end had this valorous gentleman who, had not this misfortune interyanad, with his knowledge and great intelligence, which he hed of the things of the sea and of the art of nevigation, accompanied and favored with the immense liberolity of King Frencis, would heve discovered and mede known to the worlo all that port of land up to the north. ${ }^{31}$ 
He concluded by soying that Verrazzano had great plans to colonize, develop and Christianize the land, and continue the search for a possege through those lands to Asle. Verrozzono's lest two voyoges were funded by privote individuals becouse Francis I was too heovily involved in the wors for control of italy to pursue colonizetion of the New World. How different the history of North Americe might have been hed Frencis I sponsored more of Verrazzeno's yoyages and if Verrozzeno had lived to cerry them out. 


\section{NOTES}

1 Although not an explorer himself, Antonio Pigafetto deserves mention becouse without him we would have no written record of the expedition which Magellen led out from Spain in 1519. This mission was the one which finally completed Vespucci's gool of finding a southern passage to Asia by soiling west. Although Magellen himself died in the Philippines, his crew continued on and beceme the first men to circumnevigate the globe. An impressive fleet of five ships and 237 men left Spein, but only one ship and 38 men eventually returned.

Through all of this, the scholer Pigefette maneged to survive dospits baing in the thick of denger menty times. For from baing on isoleted chronicler, Pigafetto wos an active perticipent in most of the major events of the voyege himself and described its meny hardships and perlis from firsthend expertence. A certain emount of this cen of course be attributed to the temptetion of writers to exeggerote their own role in effoirs, but his occomplishment is none the less significant. By any account, we owe a greot debt to this fine Renoissonce scholer for his bsoutifully-written account of this epic voyage. Pigafetto's own account of Magellan's voyage cen be found in Antonio Pigefette, The Voyege of Megellen: The Journal of Antonio Pigofetto, trans. Poulo Spurlin Paige (Englewood Cliffs, New Jersey: Prentice-Hall Inc. 1969).

${ }^{2}$ Lowrence Wroth, The Voyages of Glovonni do Verrezzano: 1524-1528 (Hartford, Conn.: Yole University Press, 1970), p. 56. Portions of Meneses letter relevant to Verrozzano ore quoted in Wroth, p. 229.

${ }^{3}$ Cherles E. Nowell, The Great Dlscoveries and the First Colonial Empires (Ithico and London: Cornell University Press, 1954, 10th edition, 1974), pp. 81-82.

4 James Edward Gillesple, A History of Geographical Discovery: 1400-1800 (New York: Henry Holt \& Co., 1933), pp. 65-66.

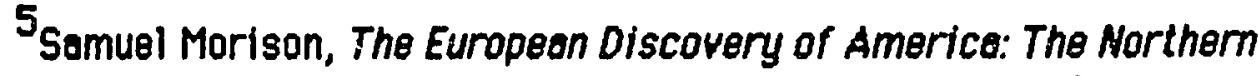
Voyzges A.D. 500-1600 (New York: Oxford University Press, 1971), p. 279.

6 Wroth, p. 11 and pp. 57-64.

7.Power of Attorney" letter, as cited in Wroth, p. 223. 
Borison, The Northem Voyages, pp. 281-282.

${ }^{9}$ Carll letter, es clied in wroth, p. 10.

${ }^{10}$ Richard Hakluyt, Divers Voyeges, os cited in Wroth, p. 162.

11 For o discussion of the Verrezzeno brothers' certogrophy and its impect see Wroth, ch. 12 and Roberto Almegit, L'Opers del Genio Italiano All'Estero, vol. 1: Gli Itoliani: I Primi Esploratori Dell'Americo IThe Italians: The First Explorers of Americoj (Rome: La Librerio Dello Stoto, 1937), pp. 365-366.

12

13 ibid., pp. 14-i6.

14 ibid., pp. 66-70.

15 Mortson, The Northern Voyoges, p. 284.

16.Céllere Codex", as cited in Wroth, pp. 133-143 in passim.

17 ibld., p. 132.

$18_{\text {Ibid., p. } 133 .}$

19 Ibid., p. 134.

${ }^{20} \mathrm{He}$ wes understandingly critical of one group of natives he encountered (in the area which would later be colled New England) who showed thair contempt for Verrazzeno's trading expedition by laughing ot them and exposing their backsides in o common gesture of ridicule and scorn. His gentlemenly, Christion sensibilities having been shocked, Verrozzeno sald that these people had "no courtesy in them" and called them "brute creetures." This humorous account is found in the Cellere Codex, os cited in Wroth, p. 141.

$21_{\text {Ibid., p. } 142 .}$

22 ibid.

23 ibid.

24 Wroth, pp. 165-177.

${ }^{25}$ Céllere Codex, as cited in Wroth, p. 143. 
${ }^{26}$ This is the interpretetion of events given by Wroth, besed upon the seemingly contradictory accounts of the voyage by the Gouveio letter of July 18, 1528 and the Meneses letter of the same date as clied in wroth, pp. 228-229.

27 Fécamp Documents, os cited in Wroth, p. 268.

28 According to the legal settlements resulting from the doomed expedition as documented in the Fécamp Documents, os cited in Wroth, p. 269.

29 Giulio Giovio, Storio Poetico, as cited in Wroth, p. 259.

${ }^{30}$ Romusio, Navigotiont et Vioggi, os cited in Wroth, p. 264.

$31_{\text {Ibid. }}$ 


\section{Chepter VI}

\section{THE IMPACT OF THE AGE OF DISCOVERY ON ITALY}

With the death of Verrazzeno the Italion Ero of Discovery ceme to a close. Italians continued to serve as valuable crewmen due to their seaforing experience, ${ }^{1}$ but the leadership of expeditions gradually began to pass into the hands of the non-Italians whom the early discoverers had trained. The notions which sponsored the Italians (with the exception of the Portuguese who had lorgeily used their own notionais from the beginning) gradually began to develop a corps of their own explorers and no longer had need of outside help. Many of these men had been apprenticed by the early discoverers and went on to make importent discoveries of their own. Lastly, the sponsoring nations developed mapmaking and novigational schools of their own as well as powerful fleets to rival those of the Italion merchants. 2

A common threed con be traced from the early speculations of Italian geographers to the explorations of Itailan alscoverers to the colonial emplres estoblished in the New World by the conquistaciors of other nations. The Itolien explorers were all influenced by Toscanelli directly or indirectly in that each one shared his dream of selling west to find a possage to the east. Each man wos olso a student of the Itelian School of 
Cartography in his own right and carried these Ideas into his methods of preperation and exploretion and eagerly tought them to others.

As we have seen, none of the Itolian explorers accomplished his direct gool of finding o westward route to Asio, but they were successiul in opening the way for others who followed after them. In addition, they made many important advances in novigational techniques and recorded observations of the people, lends, skies, and Ationtic winds and currents for those who come loter. Every mojor portion of the cosstline of the Americes wos first explored by on Itolion, end others came later to flll in the precise details and cleer up inconsistencies. Most importent of oll, it wos on Italian who first realized that the newly found land was not o part of Aslo, but the New World.

Much of the commerciel potentiol of the Naw World was pointed out first by Itolians, but it was the other Europeans who would ultimately decide how the land would be used. The great irony of the Italian Ero of Discovery is thot the benefits of the Itolians' discovery went to everyone but the ltalien states. Many thousands of miles of cosstline ware first discovered by Italians, but not one Italien colony was ever founded in the New World. Furthermore, Itely wos conquered and divided by its neighbors who ruled the weak city-states like colontes themselves. 
Leter, they used the money from their colonies to build large ormies of occupation in ltaly, thus squelching any chance of unification or independence for hundreds of yeers. Italy remeined isoleted from the economic opportunity of the New Horld and could only play a secondery role by maneging the wealth of others or hendling the distribution of goods from the New World. This sustained Itoly for perheps enother fifty years after the discovery of America, but decline was inevitable as the other notions Degan to develop their own domesitic industries to rival those of ltaly and establish their independence from the Italian commerciel network and trade monopoly. ${ }^{3}$

Italy stayed dwarfed and divided by its neighbors who had the good fortune to have unified earlier. Italion economic dominence was crushed in the struggle of the Italian states to defend themselves against foreign armies and the loss of trade markets and finance to Northern Europe. Add to this the repressiveness of the Counter-Reformation, and the Italian Reneissence died a still birth. Their finencial, sociol, politicel, ertistic, philosophicai and scholestic innovations spread throughout Europe, but nearly died out in Italy itself. 
The story of Itolian Discovery begins end ends with geogrephy. ${ }^{4}$ it was the lialians who first formed the notion of a New World, but its discovery and exploitation proved to be their downfall. Their yoyages of discovery peyed the wey for others who would exploit the resources of the New World to overihrow ltaly's dominance of the Old World. Now all that remoins of their occomplishments are ofew scettered pleces which beer their names. The mysticai lends of Antiilies, The Seven Cities of Ciboie, The Isle of Brasil, and those mysterlous lands described by Marco Polo eluded them. The names that they gave the lands that they found have nearly all bsen changed or forgotten. They did not find Asle, but the gift that they gave Europe in the form of the New World has brought Europe far more change and wealth than all the trade which wos eventually established with the Eost. 5

\section{CONCLUSION}

As we have seen, the Italien explorers of the Renaissance had humanistic motfves for their great accomplishments in the Age of Discovery. The explorers deserve a place alongside the well-known Humanists in the history of art, literature, philosophy, and government by virtue of thair reseorch and eccomplishments. Just os the Humenists in 
other flelds turned to the clessics for their inspirotion, so did the humanistic explorers become distinguished by their research in the Clessics while prepering for their yoyages. The extent of their learning has been shown by exemining their writings and the testimony of their contemporaries. The acedemic preparation of the Italion explorers was a critical foctor in estoblishing their crediblity when presenting their arguments to kings end other petrons. This is a factor which hes often been oyerlooked in traditional studies of the discoverers' lives. The explorers olso deserve credit for their originel contributions to the fields of science, nevigetion and certography. They were a breed of men who were as diligent In their search for new knowledge es eny of the noteworthy Humanist scholars.

Each of the Italian explorers contributed to our portrait of the Renaissance men as discoverer in his own way. They were not merely adventurers, but men influenced by the Humenism of their age. Because of their education and reseorch, they corried the ideas and fresh outlook of the Renaissance towards the worid with them. Speclific aspects of the Renolssance man yory from one explorer to another. Characteristics which are typically ldentified with the Renalssance man were developed to varying degrees among the different explorers. However, thelr common humanistic 
educetional beckground taught them the worth of man and inspired them to accomplish great deeds not only for God and country but also to make o neme for themselves end bring the world new knowledge.

An intellectual evolution occurred in the minds of the discovereps which wos to have for-reaching ramifications. The world view of the Reneissence explorers of itoly chenged over time as new experiences coused them to reevaluate everything that they had learned and be bold enough to change the maps to reflect their new discoveries. In generol, the explorers besed their decisions on the gathering of evidence tempered by empirical methods. Observation and experimentation allowed them to be open-minded enough to question the ancient outhorities when necessery.

The Italian discoverers also possessed the typicel Renoissence desire to bring fome to themselves through great and virtuous deeds, and to find a better understending of man and his role in the world. As this occurred, the Renoissence explorers had to come to terms with new informotion which challenged oll of the occepted notions of cosmology and cosmogrephy with which they had been ratsed and which they hed learned in their entensive reseorch of clessical geogrophers. 
A new thinking begen to develop which could comprehend the concept of a new world. This concept of a new world was formed by 0 generation of explorers who had been ralsed in en intellectual climete which taught them that they were part of a naw oge. As with ony intellectual revolution, this new thinking did not occur overnight. The realization that what they hed found was a New World was to take the course of the entire Ero of Itelien Discovery to become eccepted. Conyincing the rest of the world and claaring up the controversiss created by this revelotion would take much longer.

In the time in which the Italian discoverers lived, the introduction of the concept of a New World was to have just as profound an impect as the cloim of the other Humanists that mankind had bagun a new age. Many of the controversles created by the ideas and accomplishments of the Humenist discoverers outliyed the explorers themselves and are still being debated today. Pernaps the most important contribution of the Itallan explorers is not (os hos traditionally been maintained) the lands that they discovered, but the chenge in thinking that began to take place when the discoverers tried to explain what they had found. 


\section{NOTES}

'A complete listing of all Italians known to be involved in the Age of Discovery cen be found in the appendices of Roberto Almagia's L'Opera del Genio Iteliano All'Estero, vol. I: Gll Italiani: I Priml Esplorotori Dell'Americe [The Itelions: The First Explorers of America] (Rome: Lo Libreris Dello Steto, 1937.

2 Lawrence Wroth, The Voyages of Giovanni do Verrazzano: 1524-1528 (Hortford, Conn.: Yole University Press, 1970), pp. 255-262.

3 Jomes Edward Gillesple, A History of Geogrophical Discovery: 1400-1800 (Now York: Hanry Holt and Compony, 1933), p. 86.

${ }^{4}$ Ibid., pp. 65-66. Also see Horry A. Miskimin, The Economy of Eorly Renaissence Europe: 1300-1460 (Englewood Cliffs, New Jersey: Prentice-Holl, Inc., 1969), p. 158.

5 Poul Herrmann, The Great Age of Discovery (New York: Harper \& Brothers Publishers, 1958), p. 10. 


\section{Figure 1}

\section{Italian Yogageses of Ciscovery}

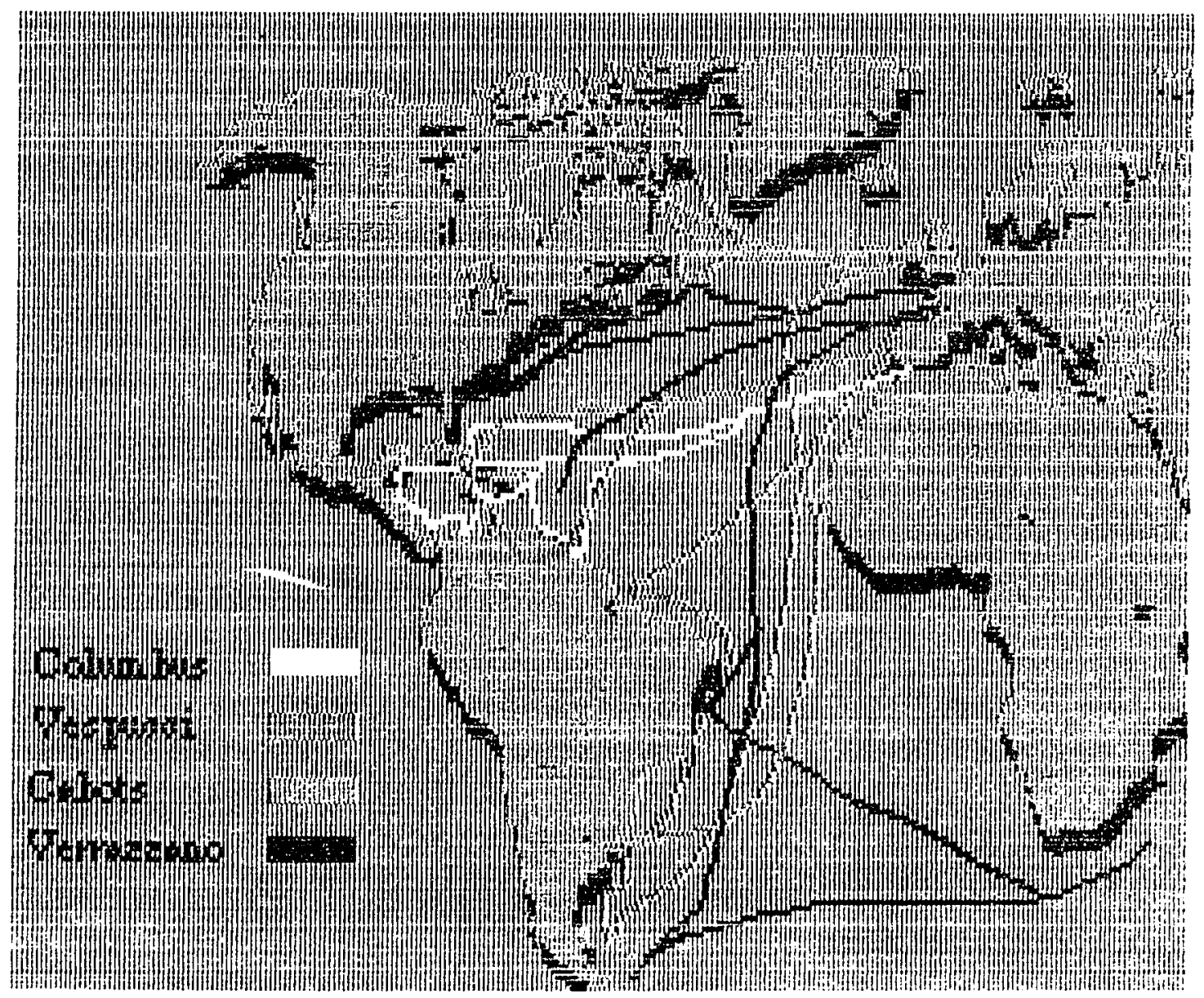


Figure 2

Chronology of the Itolien Ero of Discovery

Years of Youage
1492

1493

1497

1498

1498

1499

1501

1502

1508

$1523-24$

$1526-27$

1528

$1526-30$

\section{Discouarar \\ Columbus}

Columbus

Jơñn Coboốt

John Cobot

Columbus

Vespucci-0jede

Vespucci

Columbus

Sebostien Cobot

Varrezzeno

Verrazzano

Verrozzono

Sebostian Cobot
Area Exolarad

Ceribbeen isiends

Coribbeen islends

M้evirouñdiañ

Newfoundlend

northern coest of

South Americe

northern and eestern coests of South Americo eostern coest of South Americo

eestem coost of Centrol Amertco

Newfoundlond and Lobrador

Atlentic 88oboord of North Americo

Cope Horm and Cape of Good Hope Coribbeon

Río de la Plato 
BIBLIOGRAPHY

i. Generol Horks:

1. Almagía, Roberto. L'Opero del Genio Itoliono All'Estero. vol. 1: Gli Italiani: I Primi Esplorotori Dell'Americo IThe Itolians: The First Explorers of Americol. Rome: Lo Librerio Dello Stato, 1937.

2. Arcinieges, Germen. Americe in Europe: A History of the New World in Reverse. Translated by Gabriele Arciniegas and R. Victoria Arane. Sen Diego: Horcourt, Brace, Joyonovich, 1975.

3. Boorstin, Daniel J. The DIscoverers: A History or Man's Search to Know His World ond Himselt. New York: Rendom House Inc., 1983.

4. Burckherdt, Jacob. The Civilizetion of the Renaissence in Italy. 5th ed. London: Phaldon Press Ltd., 1937.

5. Crone, G.R. The Discovery of America. New York: Heybright \& Tolley, 1969.

6. Ferguson, Wallece. The Renaissance in Hislortcal Thought: Five Centuries of Interpretotion. Cembridge, Moss.: Houghton Mifflin, 1948.

7. Gillesple, James Edword. A History of Geogrophical Discovery: 1400-1800. New York: Henry Holt and Company, 1933. 
8. Herrmann, Poul. The Great Age of Discoveny. New York: Herper \& Brothers Publishers, 1958.

9. Miskimin, Horry A. The Economy or Early Renatssance Europe: 1300-1460. Englewood Cliffs, New Jersey: Prentice-Hell, Inc., 1969.

10. Nowell, Charles E. The Great Discoveries and the First Colonial Empires. 10th ed. Ithece end London: Cornell University Press, 1974.

11. Parry, J. H.. The Age of Reconnalssence: Discovery. Exploration and Settlement, 1450-1650. New York: Praager Publishers, 1965.

12. Penrose, Boles. Trovel and Oiscovery in the Renaissance, 1420-1620. N.p.: Hervard University Press, 1952; reprint ed., New York: Atheneum, 1975.

13. Ross, James Bruce and McLoughlin, Mary Martin ods. The Portable Renelssance Reader. New York: Penguin Books, 1981.

14. Plumb, J. H. ed. The Pelican History of European Thought. 10 vols. Hermondsworth, Middlesex: Penguin Books Lto., 1978. Vol. 3: From Humonism to Science: $1480-1700$, by Robert Mandrou. Trensiated by Brion Plerce.

15. Stephens, J. N. The Foll of the Florentine Republic 1512-1530. Oxford: Clarendon Press, 1973. 
16. Symonds, John Addington. The Reneissence in Italy: The Revival of Leerning. London: Smith, Elder \& Co. New York: Chorles Scribner's \& Sons, 1906.

II. Works on the Discoverers:

1. Arcinieges, Germen. Amerigo and the New World: The Life and Times of Amerigo Vespucci. Transleted by Harriet De Onls. New York: Alfred A. Knopf, 1955.

2. Crosby, Alfred W. Jr. The Columbian Exchange. Westport, Co.: Greenwood Press, 1972.

3. Colón, Hernando (Ferdinand Columbus). The Life of the Admiral Christopher Columbus. Translated by Benjemin Keen. New Brunswick, New Jersey: Rutgers University Press, 1959.

4. de Las Casas, Bartolome. History of the Indies. Transiated and edited by André Collerd. New York: Harper \& Row, 1971.

5. Granzotto, Gionni. Christopher Columbus. Tronsloted by Stephen Sartarelli. Garden City, NHew York: Doubleday \& Co., 1965.

6. Iglesia, Ramon ed. Columbus, Cortés, ond Other Essoys. Berkeley: University of Colifornio Press, 1969. 
7. Levillier, Roberto. Amerrice: Lo Bien Llemedo lAmerice: The Well-Nomed Landl. 2 vols. Buenos Aires: Editorlol Guiliermo Kraft Lid., 1948.

6. Levillier, Roberto. Americo Vespucio. Madrid: Ediciónes Culturo Hispenice, 1966.

9. Markhem, Clements R. trans., notes, and intro. The Letters of Amerigo Vespuccl ond Other Documents Illustrotive of HIs Coreer. New York: Burt Franklin, reprint ed., n. d. Originelly published by Hakluyt Soclety.

10. Morison, Samuel E. Admiral of the Ocean Sea: A Life of Christopher Columbus. Boston: Little, Brown and Company, 1942.

11. The European Discovery of America: The Southern

Voyoges: 1492-1616. New York: Oxford University Press, 1974.

12. . The European Discovery of America: The Northern

Voyeges A. D. 500-1600. New York: Oxford University Press, 1971.

13. Morison, Samuel E., trans. and ed. Joumals and Other Documents on the Life of Christopher Columbus. New York: The Heritoge Pross, 1963.

14. Nunn, George E. The Geographical Conceptions of Columbus: A Critical Consideration of Four Problems. Americen Geographical Society, Research Series no. 14. New York: American Geographical Society, 1929. 
15. O'Gormen, Edmundo. The Invention of Americe: An Inquiry into the Historical Nature of the New World and the Meaning of its History. Bloomington: Indiena University Press, 1961 reprint ed. by Greenwood Press, Westport, Connecticut, 1977.

16. Pigafetta, Antonio. The Voyage of Magellan: The Joumal of Antonio Pigofetto. Tronsloted by Paule Spurlin Paige. Englewood Cliffs, New Jersey: Prentice-Holl, Inc., 1969.

17. Pohl, Frederick J., Amerigo Vespucci: Pilat Major. Naw York: Colombio University Press, 1944.

18. Taviani, Emilia. Christopher Columbus: The Grond Design. London: Orbls Publishing Ltd., 1985.

19. Woldseemüller, Mortín. Cosmographioe Irtroductio. Transioted by Joseph Fischer and Franz yon Wieser. March of Americe Facsimile Series, no. 2. Ann Arbor: University Microfilms Inc., 1966.

20. Williamson, James A. The Cabat Voyages and Bristol Discovery under Henry VII. Cortogrophy of the voyoges by R. A. Skelton. Glosgow: Robert Mec Lehose a Co. Ltd. The University of Cembridge Press for the Hokluyt Society, 1962.

21. Williamson, James A. The Voyages of the Cabots and the Discovery of North Americo. London: Argonaut Press, 1929. 
22. Wroth, Lewrence C. The Voyegas of Giovanni Verrazzano:

1524-1526. Hartiord, Conn. : Connecticut Printers Inc. for the Plerpont Morgan Library and the Yale University Press, 1970.

23. Zweig, Stefon. Amerigo: A Comedy of Errors in History.

Tronslated by Andrew St. Jemes. New York: The Viking Press, 1952. 
III. Articles:

1. Goldstein, Thomes. "Florentine Humenism and the Vision of the New World" Actos do Congresso internecional do Historio Dos Descobrimentos 4 (1961): 195-207.

2. _. The Role of the Itelian Merchent Cless in Renalssance and Discoyeries" Terroe Incognitae 8(1976): 19-28.

3. ___ "Geography in Fifteenth-Century Florence" in Merchonts \& Scholors: Essoys in the History of Exploration and Trode. Edited by John Perker. Minneapoils: University of Minnesota Press, 1965.

4. ___ "15th Century Geogrophy Agoinst the Beckground of Medieval Science". A paper presented of the 4th annual meeting of the Society for the History of Discoverles, Solem, Mass., 13-14 November, 1964. (Typewritten).

5. Hirsch, Elisebeth Feist. The Discoverles and the Humenists" in Merchants \& Scholars: Essays in the HIstory of Exp atton and Trode. Edited by John Porker. Minneapolis: University of Minnesoto Press, 1965. 